\title{
A VIOLAÇÃO DA COLEGIALIDADE E DA SUSTENTABILIDADE JUDICIAL NO SUPERIOR TRIBUNAL DE JUSTIÇA: INCONSTITUCIONALIDADE POR PRÁTICA VICIADA REITERADA ${ }^{1}{ }^{2}$
}

INFRINGEMENT OF THE COLLEGIALITY AND JUDICIAL SUSTAINABILITY IN THE HIGHER COURT OF JUSTICE: UNCONSTITUTIONALITY BY REPEATED ADDICTIVE PRACTICE

Magno Federici Gomes Estágio Pós-doutoral em Direito Público e Educação pela Universidade Nova de Lisboa-Portugal (Bolsa CAPES/BEX 3642/07-0). Estágios Pós-doutorais em Direito Civil e Processual Civil, Doutor em Direito e Mestre em Direito Processual, pela Universidad de Deusto-Espanha (Bolsa da Cátedra UNESCO e do Gobierno Vasco-Espanha). Mestre em Educação pela PUC Minas. Coordenador e professor do Doutorado e Mestrado Acadêmico em Direito Ambiental e Desenvolvimento Sustentável na Escola Superior Dom Helder Câmara. Advogado Sócio do Escritório Moraes \& Federici Advocacia Associada. Belo Horizonte/MG. ORCID: http://orcid.org/0000-0002-4711-5310. E-mail: magnofederici@gmail.com.

Janaina Ferreira da Silva Santos Especialista em Direito Ambiental pelo Complexo de Ensino Renato Saraiva (Faculdade CERS/Curso CEI). Especialista em Direito Civil Contemporâneo pelo Centro de Estudos em Direito e Negócios (CEDIN). Graduada pelo Curso de Direito da Pontifícia Universidade Católica de Minas Gerais (PUC

\footnotetext{
${ }^{1}$ Artigo recebido em 13/08/2021 e aprovado em 07/12/2021.

${ }^{2}$ Trabalho financiado pelo Edital 03/2020 da Escola Superior Dom Helder Câmara, resultante dos Grupos de Pesquisas (CNPQ): Responsabilidade Civil e Processo Ambiental (RECIPRO), NEGESP, Metamorfose Jurídica e CEDIS.
} 
Minas). Advogada. Estagiária de pós-graduação no Tribunal de Justiça do Estado de Minas Gerais (TJMG). Belo Horizonte/MG. ORCID: http://orcid.org/0000-0003-35851801. E-mail: janainaf.advocacia@gmail.com.

Jorge Isaac Torres Manrique Doutor em Direito e Administração pela UNFV (Lima-Peru). Presidente da Escola Interdisciplinar de Direitos Fundamentais Praeeminentia Iustitia (Peru). Membro da Associação Internacional de Direito Constitucional - IACL (Sérvia). Membro da Associação Mundial pela Justiça Constitucional (Colômbia). Membro do Comitê Científico Internacional do International Legal Institute of Torino (Itália). Vice membro estrangeiro da Associação Argentina de Justiça Constitucional (Argentina). Membro Sênior da Associação Colombiana de Direito Processual Constitucional (Colômbia). Membro do Instituto Vasco de Direito Processual (País Vasco). Consultor jurídico. Advogado militante pela UCSM (Arequipa). Lima, Perú. ORCID: http://orcid.org/0000-0001-5202-3886.

E-mail: kimblellmen@outlook.com.

RESUMO: O respeito ao princípio da colegialidade pelo Superior Tribunal de Justiça (STJ) é o objeto deste artigo. Acerca do resultado do julgamento dos recursos interpostos contra as decisões monocráticas proferidas no STJ, elaborou-se uma pesquisa teórico documental, com base empírica quantitativa em menor grau, pelo método indutivo. Constatou-se que o STJ inviabiliza a revisão material das decisões monocráticas pelo órgão colegiado, objetivando aumentar a celeridade dos julgamentos, o que é uma prática inconstitucional. Identificou-se conflito entre os princípios da razoável duração do processo e da colegialidade, que foi solucionado pelo postulado da proporcionalidade. 
PALAVRAS-CHAVE: Superior Tribunal de Justiça; princípio da colegialidade; decisão monocrática; princípio da razoável duração do processo; inconstitucionalidade.

ABSTRACT: Respect for the principle of collegiality by the Higher Court of Justice is the object of this paper. Regarding the outcome of the appeals against the monocratic decisions handed down in the Higher Court of Justice, a documentary theoretical research was developed, based on quantitative empirical to a lesser degree, by the inductive method. It was found that the Higher Court of Justice prevents the material review of monocratic decisions by the collegiate body, aiming to increase the speed of judgments, which is an unconstitutional practice. It was identified conflict between the principles of reasonable duration of the process and collegiality, solved by the postulate of proportionality.

KEYWORDS: Higher Court of Justice; principle of collegiality; monocratic decision; principle of reasonable duration of the process; unconstitutionality.

\section{INTRODUÇÃO}

No Brasil, a crescente sobrecarga dos tribunais desembocou na adoção de medidas que pudessem reduzir o acervo processual, a fim de aumentar a celeridade na tramitação dos feitos. Neste contexto, a legislação processual pátria atribuiu amplos poderes ao relator e ao presidente dos tribunais, os quais, podem, até mesmo, proferir decisões monocráticas analisando a admissibilidade e o mérito dos recursos e das ações de competência originária dos tribunais, em algumas hipóteses legais. Contra essas decisões monocráticas são cabíveis os recursos de agravo interno e agravo regimental, que levam a apreciação da questão ao órgão colegiado.

Diante disso, o presente trabalho analisa os recursos de agravo interno e agravo regimental interpostos contra as decisões monocráticas proferidas pelo Superior Tribunal de Justiça (STJ), a partir da função de tais recursos de proporcionar o respeito ao princípio da colegialidade. Destarte, a problemática é desvelar se o STJ, ao julgar os recursos interpostos contra as decisões monocráticas proferidas pelo relator ou pelo presidente do STJ, viola, ou não, o princípio da colegialidade, incorrendo em prática inconstitucional. 
Sendo assim, o objetivo geral da pesquisa é investigar em que medida o STJ respeita o princípio da colegialidade. Para isso, foram traçados como objetivos específicos: apresentar o caráter constitucional do princípio da colegialidade nos tribunais; verificar se o agravo interno e o agravo regimental no STJ cumprem a função de possibilitar a análise da decisão monocrática pelo órgão colegiado; e, por fim, a partir da força normativa atribuída aos princípios no neoconstitucionalismo, investigar se há inconstitucionalidade no julgamento dos agravos internos e agravos regimentais interpostos contra as decisões monocráticas proferidas no STJ.

Para tanto, analisa-se a legislação constitucional e infraconstitucional e a doutrina pertinentes ao tema, a fim de expor a força normativa atribuída aos princípios no neoconstitucionalismo; delinear os contornos dos princípios da colegialidade e da duração razoável do processo; destacar a importância do cabimento do agravo interno e do agravo regimental contra as decisões monocráticas proferidas nos tribunais, como forma de efetivação do princípio da colegialidade. Ato contínuo, a fim de analisar a possível violação do princípio da colegialidade pelo STJ, adota-se a metodologia teórico documental, com base empírica quantitativa em menor grau, baseada na análise de dados estatísticos extraídos do site do STJ, no período de janeiro a agosto de 2019, com técnica indutiva, a respeito do resultado do julgamento dos recursos de agravo interno e agravo regimental interpostos contra as decisões monocráticas proferidas no STJ.

Com o objetivo de solucionar o problema exposto, o artigo foi desenvolvido em três tópicos. No primeiro, apresentou-se o conceito e o surgimento do neoconstitucionalismo, bem como o conceito de recurso e o caráter constitucional do princípio da colegialidade. No segundo, abordou-se a possibilidade de proferir decisão monocrática nos recursos e nas ações de competência originária dos tribunais e o cabimento dos recursos de agravo interno e agravo regimental contra essas decisões. No terceiro, diante da existência de conflito entre os princípios constitucionais da razoável duração do processo e da colegialidade, questionou-se a existência de prática inconstitucional no STJ, a partir da aplicação do postulado da proporcionalidade, adotando como marco teórico a teoria dos princípios desenvolvida por Ávila .

\footnotetext{
${ }^{3}$ ÁVILA, Humberto. Teoria dos princípios: da definição à aplicação dos princípios jurídicos. 4. ed., rev. São Paulo: Malheiros, 2005.
} 
O estudo justifica-se em razão da importância tanto do princípio da colegialidade quanto do princípio da razoável duração do processo para a manutenção do modelo constitucional de processo democrático. Isto porque, o princípio da colegialidade é corolário dos princípios do juízo natural, da imparcialidade, da ampla defesa e do contraditório nos tribunais. Por sua vez, a razoável duração do processo é uma condição de eficácia da tutela jurisdicional.

\section{NEOCONSTITUCIONALISMO E PRINCÍPIOS RELEVANTES À PESQUISA}

O neoconstitucionalismo surge no contexto da pós-modernidade, tendo por base premissa já existente no modelo constitucionalista: a supremacia da constituição. A gênese do constitucionalismo é justificada pela necessidade de criar formas capazes de controlar o poder absolutista atribuído ao chefe do estado nacional, após a ruptura do sistema feudal. O constitucionalismo se consolidou, aproximadamente, no fim do século XVIII, a partir de movimentos como a Revolução Norte-Americana e a Revolução Francesa, das quais derivaram, respectivamente, a Constituição dos Estados Unidos da América (EUA) de 1787 e a Constituição Francesa de $1791^{4}$. Essas revoluções foram engajadas por ideais próprios do jusnaturalismo, segundo o qual, o homem possui direitos naturais, a exemplo da liberdade e da integridade, que devem ser respeitados, inclusive pelo estado, posto que são inerentes ao ser humano. Tendo em vista o cenário anterior, em que a vontade do governante se sobrepunha à do povo, o advento do constitucionalismo e sua evolução consagrou grandes feitos como:

[...] (i) legitimidade - soberania popular na formação da vontade nacional, por meio do poder constituinte; (ii) limitação do poder repartição de competências, processos adequados de tomada de decisão, respeito aos direitos individuais, inclusive das minorias; (iii) valores incorporação à Constituição material das conquistas sociais, políticas e éticas acumuladas no patrimônio da humanidade 5 .

No século XIX, o estado moderno, no âmbito do qual surgiu o constitucionalismo, passa a adotar um modelo de Direito positivista e racional, almejando sua configuração

\footnotetext{
${ }^{4}$ FERNANDES, Ricardo Vieira de Carvalho; BICALHO, Guilherme Pereira Dolabella. Do positivismo ao pós-positivismo jurídico: $\mathrm{O}$ atual paradigma jusfilosófico constitucional. Revista de Informação Legislativa, Brasília, v. 48, nº 189, p. 105-131, jan./mar. 2011. p. 106. Acesso: 30/11/2019.

${ }_{5}^{5}$ BARROSO, Luís Roberto. Fundamentos teóricos e filosóficos do novo direito constitucional brasileiro. Revista da EMERJ, Rio de Janeiro, v. 4, nº 15, p. 11-47, 2001. p. 18. Acesso: 29/11/2019.
} 
como uma ciência pura ${ }^{6}$. Neste contexto, o papel do Juiz como aplicador do Direito era restritamente limitado pela separação de poderes, cabendo-lhe o exercício "silogístico de subsunção dos fatos à norma"7, previamente e abstratamente posta, sendo vedado, portanto, qualquer interpretação criativa do Direito. Assim, o positivismo jurídico se tornou um forte aliado da manutenção do status quo, independentemente de qual fosse ele, pois positivada a norma pela autoridade competente, a discussão sobre sua aceitação jurídica praticamente se encerrava, diante da impossibilidade de realizar a análise valorativa acerca da justiça de uma norma posta ${ }^{8}$.

Ao final da Segunda Guerra Mundial, era inconcebível a perpetuação do positivismo jurídico. Atrocidades foram cometidas em nome da lei, que não dependia de verificação axiológica no campo da justiça ou da ética ${ }^{9}$. Superados tanto o jusnaturalismo quanto o positivismo, surge a era do pós-positivismo. Segundo Barroso ${ }^{10}$, trata-se de uma “designação provisória e genérica de um ideário difuso, no qual se incluem a definição das relações entre valores, princípios e regras, aspectos da chamada nova hermenêutica e a teoria dos direitos fundamentais". Desse modo, o neoconstitucionalismo estabelece uma "confluência das duas correntes anteriores"11 e reconhece que o Direito não abrange apenas as normas positivadas, enfatizando a função dos princípios constitucionais de assegurar os valores essenciais ao Estado Democrático de Direito, no qual, o poder emana do povo, todos se submetem a leis previamente estabelecidas e existe um sistema de proteção aos direitos humanos e fundamentais.

\footnotetext{
${ }^{6}$ Hans Kelsen, ao formular a teoria pura do direito, dissociou o conceito valorativo de justiça do campo de validade do direito positivo, que para o autor, independe de conceitos inerentes ao direito natural (KELSEN, Hans. Teoria pura do direito. Tradução de João Batista Machado. 6. ed. São Paulo: Martins Fontes, 1998. p. 135-153).

${ }^{7}$ BARROSO, Luís Roberto. Fundamentos teóricos e filosóficos do novo direito constitucional brasileiro. Revista da EMERJ, Rio de Janeiro, v. 4, n 15, p. 11-47, 2001. p. 20. Acesso: 29/11/2019.

${ }^{8}$ BARROSO, Luís Roberto. Fundamentos teóricos e filosóficos do novo direito constitucional brasileiro. Revista da EMERJ, Rio de Janeiro, v. 4, n 15, p. 11-47, 2001. p. 31. Acesso: 29/11/2019.

9 BARROSO, Luís Roberto. Fundamentos teóricos e filosóficos do novo direito constitucional brasileiro. Revista da EMERJ, Rio de Janeiro, v. 4, n 15, p. 11-47, 2001. p. 31. Acesso: 29/11/2019.

${ }^{10}$ BARROSO, Luís Roberto. Fundamentos teóricos e filosóficos do novo direito constitucional brasileiro. Revista da EMERJ, Rio de Janeiro, v. 4, n 15, p. 11-47, 2001. p. 31. Acesso: 29/11/2019.

${ }^{11}$ FERNANDES, Ricardo Vieira de Carvalho; BICALHO, Guilherme Pereira Dolabella. Do positivismo ao pós-positivismo jurídico: $\mathrm{O}$ atual paradigma jusfilosófico constitucional. Revista de Informação Legislativa, Brasília, v. 48, nº 189, p. 105-131, jan./mar. 2011. p. 113. Acesso: 30/11/2019.
} 
Dworkin $^{12}$, ao distinguir os princípios das regras, ensina que estas são caracterizadas por preverem abstratamente uma hipótese e a consequência de sua ocorrência, assim, aplicam-se por meio de subsunção do fato à previsão legal. Para ele, as regras obedecem ao método do "tudo-ou-nada" ${ }^{13}$, segundo o qual, "dados os fatos que uma regra estipula, então ou a regra é válida, e neste caso a resposta que ela fornece deve ser aceita, ou não é válida, e neste caso nada contribui para a decisão"14. Isto porque, o conflito entre as regras se resolve por critérios de hierarquia, especialização e cronologia, ou seja, uma regra superior, específica ou posterior derroga uma regra inferior, geral ou anterior ${ }^{15}$. Por sua vez, os princípios - por exprimirem direitos fundamentais e valores éticos comportam carga valorativa maior que as regras. Por isso, havendo conflito entre dois princípios "aquele que vai resolver o conflito tem de levar em conta a força relativa de cada um" ${ }^{\prime 16}$. Porém, a escolha por um dos princípios aplicáveis ao caso concreto não nega validade e existência ao outro, pois, segundo Dworkin, o princípio "é uma exigência de justiça ou equidade ou alguma outra dimensão da moralidade" ${ }^{17}$.

Dworkin foi um dos primeiros autores a destacar-se ao estabelecer uma contraposição ao positivismo. Também contribuíram significativamente para o neoconstitucionalismo - embora seja possível constatar divergências nas teorias apresentadas por eles - Alexy ${ }^{18}$ e Ávila ${ }^{19}$. Ávila discorda da teoria de Dworkin, segundo a qual, a aplicabilidade das regras é verificada pelo critério do "tudo ou nada". Para Ávila,

\footnotetext{
${ }^{12}$ DWORKIN, Ronald. Levando os direitos a sério. Tradução de Nelson Boeira. São Paulo: Martins Forense, 2002. p. 39

${ }^{13}$ DWORKIN, Ronald. Levando os direitos a sério. Tradução de Nelson Boeira. São Paulo: Martins Forense, 2002. p. 39.

${ }^{14}$ DWORKIN, Ronald. Levando os direitos a sério. Tradução de Nelson Boeira. São Paulo: Martins Forense, 2002. p. 39.

${ }^{15}$ DWORKIN, Ronald. Levando os direitos a sério. Tradução de Nelson Boeira. São Paulo: Martins Forense, 2002. p. 43.

${ }^{16}$ DWORKIN, Ronald. Levando os direitos a sério. Tradução de Nelson Boeira. São Paulo: Martins Forense, 2002. p. 42.

${ }^{17}$ DWORKIN, Ronald. Levando os direitos a sério. Tradução de Nelson Boeira. São Paulo: Martins Forense, 2002. p.36.

${ }^{18}$ ALEXY, Robert. Teoria dos Direitos Fundamentais. Tradução de Virgílio Afonso da Silva. 2 ed. São Paulo: Malheiros, 2008.

${ }_{19}$ ÁVILA, Humberto. Teoria dos princípios: da definição à aplicação dos princípios jurídicos. 4. ed., rev. São Paulo: Malheiros, 2005.
} 
tanto a aplicação dos princípios quanto das regras pode envolver "aspectos específicos, abstratamente considerados" 20 .

Dito isso, frise-se que o principal objetivo do pós-positivismo foi combater a falta de critérios materiais para valoração das normas, implementando "direitos constitucionais a partir de verificação axiológica das normas aplicáveis" ${ }^{21}$. Destarte, na contemporaneidade, reconheceu-se a força normativa dos princípios constitucionais, explícitos ou implícitos, bem como a sua aplicabilidade imediata. Barroso lista três funções precípuas dos princípios: “a) condensar valores; b) dar unidade ao sistema; c) condicionar a atuação do intérprete" ${ }^{22}$.

Sendo assim, os princípios tutelam os valores essenciais da sociedade, de maneira que os princípios norteadores de um instituto jurídico são parâmetros para a interpretação e aplicação de todas as suas normas. Dessa forma, no neoconstitucionalismo, vincula-se não só a criação das leis aos direitos e garantias constitucionais, mas também a sua interpretação e aplicação. O processo aparece, portanto, como um instrumento adequado e necessário à concretização das garantias e direitos assegurados pelo Estado Democrático de Direito $^{23}$.

Assim, tendo em vista "que um princípio prescreve um direito e, por isso, contém uma exigência de justiça, equidade ou devido processo legal" ${ }^{24}$, conclui-se que os princípios constitucionais aplicáveis à tramitação dos processos nos tribunais — como normas fundamentais que regem o sistema recursal e as ações de competência originária devem ser observados em proporções que possibilitem aumentar o nível de correção, justiça e efetividade das decisões judiciais. Esse nível é aferido conforme o grau de respeito da decisão às garantias e princípios constitucionais - cite-se o contraditório, a

\footnotetext{
${ }^{20}$ ÁVILA, Humberto. Teoria dos princípios: da definição à aplicação dos princípios jurídicos. 4. ed., rev. São Paulo: Malheiros, 2005 p. 39.

${ }^{21}$ FERNANDES, Ricardo Vieira de Carvalho; BICALHO, Guilherme Pereira Dolabella. Do positivismo ao pós-positivismo jurídico: O atual paradigma jusfilosófico constitucional. Revista de Informação Legislativa, Brasília, v. 48, no 189, p. 105-131, jan./mar. 2011. p.113. Acesso: 30/11/2019.

${ }^{22}$ BARROSO, Luís Roberto. Fundamentos teóricos e filosóficos do novo direito constitucional brasileiro. Revista da EMERJ, Rio de Janeiro, v. 4, nº 15, p. 11-47, 2001. p. 33-34. Acesso: 29/11/2019.

${ }^{23}$ GOMES, Magno Federici; MARTINS, Márcia de Azevedo. A inconstitucionalidade do artigo 475 do Código de Processo Civil: violação aos princípios da isonomia, proporcionalidade e efetividade do procedimento. Revista Eletrônica de Direito Processual, Rio de Janeiro, v. 6, nº 6, p, 428-474, jul./dez. 2010. p. 445-447. Acesso: 19/11/2019.

${ }^{24}$ THEODORO JUNIOR, Humberto; NUNES, Dierle; BAHIA, Alexandre; PEDRON, Flávio. Novo CPC: Fundamentos e sistematização. 3. ed. rev., atual. e ampl. Rio de Janeiro: Forense, 2016. p. 60.
} 
ampla defesa, o juízo natural e o amplo acesso à jurisdição ${ }^{25}$ - a fim de atingir o devido processo legal, e, portanto, uma decisão justa ${ }^{26}$.

Por fim, importante destacar que o caráter de direito fundamental atribuído aos princípios constitucionais e a maior preocupação com a valoração da justiça, desembocou em uma constante demanda pela promoção da dignidade da pessoa humana e do respeito aos direitos humanos. Isso com o objetivo de assegurar o mínimo existencial ${ }^{27}$ para a preservação da vida digna da presente e das futuras gerações, alcançando o desenvolvimento sustentável ${ }^{28}$.

Nesse sentido, Bodnar alerta para o perigo de uma patologia social consistente na “desvinculação progressiva de uma racionalidade axiológica em direção à razão técnica que distancia e desvincula os seres humanos da natureza na busca do progresso a qualquer custo" ${ }^{29}$. Por isso, a decisão judicial não pode se restringir ao mero exercício de subsunção do fato à norma. A jurisdição enfrenta um desafio hermenêutico de formação da decisão judicial por meio da ponderação, da dialeticidade e da participação, além de contar com o auxílio de outras áreas do saber, visando, inclusive, prever os resultados do pronunciamento judicial para o futuro ${ }^{30}$.

\subsection{O recurso como forma de exercício dos princípios do contraditório e da ampla defesa}

${ }^{25}$ Pelo princípio do amplo acesso à jurisdição ou inafastabilidade do controle jurisdicional tem-se que "todos, indistintamente, têm direito à busca da tutela jurisdicional justa, adequada e efetiva”. (GOMES, Magno Federici. Do amplo acesso à juridição e da (in) aplicabilidade da retenção dos recursos especial e extraordinário. Revista Eletrônica de Direito processual, Rio de janeiro, v. 8, no 8, p. 679-708, jul./dez. 2011. p. 703). Acesso: 01/12/2019.

${ }^{26}$ Salienta-se que uma decisão justa apenas pode ser obtida por meio de um processo também justo. "O processo justo (ou democrático), garantido pela ordem constitucional, é aquele que se volta para as garantias processuais constitucionais, dentro dos padrões do devido processo legal." (THEODORO JUNIOR, Humberto; NUNES, Dierle; BAHIA, Alexandre; PEDRON, Flávio. Novo CPC: Fundamentos e sistematização. 3. ed. rev., atual. e ampl. Rio de Janeiro: Forense, 2016. p. 84).

27 O mínimo existencial é aquela parcela de condições materiais indispensáveis à sobrevivência e à preservação da liberdade do homem. A efetivação do mínimo existencial depende do processo democrático, pois, há vários instrumentos judiciais voltados para garanti-lo. (TORRES, Ricardo Lobo. O mínimo existencial e os direitos fundamentais. Revista de Direito Administrativo, Rio de Janeiro, v. 177, p. 29-49, jul./set. 1989. p. 46).

${ }^{28}$ GOMES, Magno Federici; FERREIRA, Leandro José. A dimensão jurídico-política da sustentabilidade e o direito fundamental à razoável duração do procedimento. Revista do Direito, Santa Cruz do Sul, v. 2, nº 52, p. 93-111, maio/set. 2017. p. 104. Acesso: 27/08/2019.

${ }_{29}$ BODNAR, Zenildo. Os novos desafios da jurisdição para a sustentabilidade na atual sociedade de risco. Veredas do Direito, Belo Horizonte, v. 6, n 12, p. 101-119, julho/dez. 2009. p. 105. Acesso: 28/08/2019.

${ }^{30}$ BODNAR, Zenildo. Os novos desafios da jurisdição para a sustentabilidade na atual sociedade de risco. Veredas do Direito, Belo Horizonte, v. 6. n 12, p. 101-119, julho/dez. 2009. p. 106. Acesso: 28/08/2019. 
Inicialmente, cumpre pontuar que os recursos são meios voluntários de impugnação às decisões judiciais, que objetivam a obtenção da reforma, da invalidação, da cassação, do esclarecimento ou da integração do julgado. O recurso é a continuação do exercício do direito de ação, posto que se desenvolve no mesmo processo que o originou, ou seja, não tem natureza de ação autônoma. A doutrina atribuiu aos recursos o caráter de garantia constitucional, uma vez que são imprescindíveis ao exercício satisfatório do contraditório e da ampla defesa.

A Constituição da República Federativa do Brasil (CRFB), em seu art. 5º inciso $\mathrm{LV}^{31}$, prevê como uma garantia fundamental o exercício do contraditório e da ampla defesa. O primeiro pode ser entendido como uma garantia que ultrapassa a bilateralidade de audiência e a paridade de armas, assegurando a influência nas decisões judiciais e vedando que estas sejam proferidas em caráter surpresa ${ }^{32}$. O segundo estabelece a necessidade de que a parte possa se defender, isto é, reagir aos atos processuais dos quais pode sofrer ou tenha sofrido os efeitos ${ }^{33}$.

Logo, o recurso ganha status de garantia constitucional, pois propicia o exercício do contraditório e da ampla defesa não só em face dos argumentos trazidos pela contraparte, como também em face da decisão judicial e de seus fundamentos, por meio de uma defesa sucessiva $^{34}$. Assim, os recursos são indispensáveis ao modelo democrático e comparticipativo de processo, uma vez que "no paradigma de Estado Democrático o Direito precisa legitimar-se por meio de procedimentos que devem estar de acordo com os direitos fundamentais e com o princípio da soberania do povo" ${ }^{35}$. Sendo certo que a supressão da possibilidade de impugnar o pronunciamento judicial causaria perpetuação de

\footnotetext{
${ }^{31}$ Art. $5^{\circ}$, inciso LV, da CRFB: "aos litigantes, em processo judicial ou administrativo, e aos acusados em geral são assegurados o contraditório e ampla defesa, com os meios e recursos a ela inerentes".

32 THEODORO JUNIOR, Humberto; NUNES, Dierle; BAHIA, Alexandre; PEDRON, Flávio. Novo CPC: Fundamentos e sistematização. 3. ed. rev., atual. e ampl. Rio de Janeiro: Forense, 2016. p. 122-133.

${ }^{33}$ NUNES, Dierle José Coelho. Direito Constitucional ao Recurso: Da teoria geral dos recursos, das reformas processuais e da comparticipação nas decisões. Rio de Janeiro: Lumen Juris, 2006. p. 149-150. Acesso: 17/10/2019.

${ }^{34}$ NUNES, Dierle José Coelho. Direito Constitucional ao Recurso: Da teoria geral dos recursos, das reformas processuais e da comparticipação nas decisões. Rio de Janeiro: Lumen Juris, 2006. p. 163. Acesso: $17 / 10 / 2019$.

${ }^{35}$ NUNES, Dierle José Coelho. Direito Constitucional ao Recurso: Da teoria geral dos recursos, das reformas processuais e da comparticipação nas decisões. Rio de Janeiro: Lumen Juris, 2006. p. 137-138. Acesso: 17/10/2019.
} 
decisões incorretas, injustas ou surpresas, pois, o recurso, possibilita realizar o controle ${ }^{36} \mathrm{e}$ a revisão das decisões.

\subsection{O caráter constitucional do princípio da colegialidade pela existência do juiz natural}

O juízo natural para julgamento dos recursos e dos processos de competência originária dos tribunais é o órgão colegiado ${ }^{37}$. Dessa maneira, o princípio da colegialidade está atrelado ao princípio do juízo natural, amparado expressamente pela CRFB como garantia fundamental. Importante mencionar que o princípio do juízo natural pode ser compreendido sob duas perspectivas ${ }^{38}$. Na primeira, ele veda a criação de tribunais de exceção ${ }^{39}$, voltados para o julgamento e processamento de casos específicos. Assim, o juízo natural é aquele previsto abstratamente, antes da ocorrência do fato, para julgar um número indeterminado de casos semelhantes. Na segunda, o princípio do juízo natural assegura que um indivíduo apenas pode ser processado e sentenciado pela autoridade competente $^{40}$.

A CRFB elenca, em seu art. 92, os órgãos integrantes do poder judiciário e, posteriormente, delimita a competência de cada um deles ${ }^{41}$. Nesta pesquisa, é importante destacar que a competência e a composição do STJ são definidas, respectivamente, pelo art. 105 e pelo art. 104, ambos da CRFB. Desse modo, nos casos em que o STJ é competente para processamento e/ou julgamento do feito, é implícito que o juízo natural é

\footnotetext{
${ }^{36}$ A este respeito Medina salienta que "os recursos seriam, de acordo com parte da doutrina, meios de controle, já que o Estado não pode garantir que os juízes sejam infalíveis" (MEDINA, José Miguel Garcia. Curso de Direito Processual Civil Moderno. 3. ed. rev., atual. e ampl. São Paulo: Revista dos Tribunais, 2017. p. 1189).

${ }^{37}$ SCARPINELLA BUENO, Cassio. Manual de direito processual civil. 4. ed. São Paulo: Saraiva, 2018. p. 1104-1105.

${ }^{38}$ NUNES, Dierle José Coelho. Colegialidade das decisões dos Tribunais - Sua Visualização como Princípio Constitucional e do Cabimento de Interposição de Agravo Interno de Todas as Decisões Monocráticas do Relator. Revista IOB de Direito Processual Civil, Brasília, v. 9, nº 50, p. 50-61, nov./dez. 2007. p. 52.

${ }^{39}$ Art. $5^{\circ}$, inciso XXXVII da CRFB: "não haverá juízo ou tribunal de exceção". (BRASIL. [Constituição (1988)]. Constituição da República Federativa do Brasil de 1988. Diário Oficial da União, Brasília, 05 out. 2019). Acesso: 25/11/2019.

40 Art. $5^{\circ}$, inciso LIII, da CRFB: "ninguém será processado nem sentenciado senão pela autoridade competente". (BRASIL. [Constituição (1988)]. Constituição da República Federativa do Brasil de 1988. Diário Oficial da União, Brasília, 05 out. 2019). Acesso: 25/11/2019.

${ }^{41}$ CHAVES, Jéssica Galvão. Princípio constitucional da colegialidade na formação da decisão pluripessoal. 154f. 2017. Dissertação (Mestrado em Direito) - Pontifícia Universidade Católica de Minas Gerais, Belo Horizonte, 2017. p. 46. Acesso: 13/10/2019.
} 
o órgão colegiado, pois, no Brasil, é inerente aos tribunais a formação da decisão pluripessoal por deliberação dos membros do órgão colegiado, proferindo-se o acórdão ao final.

Ademais, a natureza constitucional do princípio da colegialidade é reforçada ao verificar-se que, no âmbito dos tribunais, a apreciação do mérito do recurso unipessoalmente deve amparar-se em precedente originado de órgãos colegiados ${ }^{42}$. Ainda que esta decisão monocrática seja fundamentada em entendimento firmado por órgão pluripessoal, é cabível sua revisão por meio da interposição dos recursos de agravo interno ou regimental, que levam a análise da controvérsia para o órgão colegiado.

Sendo assim, o princípio da colegialidade encontra amparo normativo constitucional, porque o órgão colegiado é o juízo natural para o julgamento dos recursos e das ações de competência originária dos tribunais. Além disso, o princípio da colegialidade funciona como garantidor dos princípios da imparcialidade ${ }^{43}$, do contraditório e da ampla defesa, conforme apresentado nos dois subtópicos seguintes.

\subsection{O princípio da colegialidade como forma de amenizar interferências subjetivas nas decisões judiciais, visando o ideal de imparcialidade do julgador}

Diante da possível falibilidade da decisão monocrática, surge a possibilidade de interpor recurso a ser analisado por órgão colegiado. A finalidade precípua da revisão das decisões judiciais por órgãos colegiados é elevar a legitimidade da decisão emanada do Estado-Juiz, uma vez que ameniza vícios subjetivos aos quais estão sujeitos os julgadores singulares $^{44}$. De acordo com Nunes, Silva e Pedron, há estudos demonstrando que esses

\footnotetext{
${ }^{42}$ CHAVES, Jéssica Galvão. Princípio constitucional da colegialidade na formação da decisão pluripessoal. 154f. 2017. Dissertação (Mestrado em Direito) - Pontifícia Universidade Católica de Minas Gerais, Belo Horizonte, 2017. p. 48-57. Acesso: 13/10/2019.

${ }^{43} \mathrm{O}$ texto da CRFB não elenca de forma expressa o princípio da imparcialidade, mas a partir de uma análise sistêmica denota-se a sua natureza constitucional, pois, o art. 95 da CRFB prevê disposições que visam assegurar a imparcialidade e independência dos juízes, sendo possível citar, ainda, a garantia do juízo natural, insculpida no art. $5^{\circ}$. Além disso, a Convenção Americana sobre Direitos Humanos - aprovada nos termos do art. $5^{\circ}, \S 3^{\circ}$, da CRFB, possuindo, portanto, força de Emenda Constitucional - garante, em seu art. $8^{\circ}$ que "Toda pessoa tem direito a ser ouvida, com as devidas garantias e dentro de um prazo razoável, por um juiz ou tribunal competente, independente e imparcial" (BRASIL. Decreto n ${ }^{\circ}$ 678, de 06 de novembro de 1992. Promulga a Convenção Americana sobre Direitos Humanos (Pacto de São José da Costa Rica), de 22 de novembro de 1969. Diário Oficial da União, Brasília, 09 nov. 1992). Acesso: 19/11/2019.

${ }^{44}$ A contaminação do julgador no curso do conhecimento do processo poderia ocorrer em razão de preconceitos, bem como pela imposição implícita de atendimento a requisitos de celeridade no provimento
} 
vícios subjetivos ocorrem em razão da tendência do ser humano de agir e tomar decisões com base em emoções, instinto e intuições, para "resolver problemas cotidianos a partir da lógica do menor esforço, aplicável também à capacidade cognitiva humana" ${ }^{45}$. Os referidos autores mencionam que:

O processo intuitivo funciona a partir do acúmulo de conhecimento acerca de informações em geral ao longo da vida humana. Em um momento posterior, quando deparado com uma situação que envolva informações preteritamente conhecidas, o ser humano tende a, automaticamente, se valer da informação constante de seu banco de dados mental de modo a formular respostas cognitivas automáticas. [...] Entretanto, há situações em que a resposta intuitiva proporcionada pelo mecanismo cognitivo poderá estar baseada em premissas duvidosas, levando a conclusões equivocadas ${ }^{46}$.

Dentre as diversas espécies de vieses de cognição que afetam a tomada de decisão do ser humano ao se deparar com um determinado problema, Silva ${ }^{47}$ destaca os seguintes, uma vez que relacionados à atividade judicante: a) viés de confirmação, que se manifesta quando o Juiz tende a buscar elementos processuais, de direito e de fato, aptos a confirmar suas preconcepções a respeito do caso; b) viés de trancamento, em razão do qual o julgador tende a manter decisão anteriormente proferida em cognição sumária, mesmo existindo evidências que infirmem tal decisão, pois já empreendeu tempo e recursos para solucionar o caso; c) viés de retrospectiva, que pode viciar a análise de um fato em virtude de um acontecimento posterior que à época do fato era imprevisível ${ }^{48} ;$ d) viés de ancoragem e

judicial, mesmo diante do elevado número do acervo; assim, no julgamento solitário ele estaria mais vulnerável a uma "ilusão cognitiva" (THEODORO JUNIOR, Humberto; NUNES, Dierle; BAHIA, Alexandre; PEDRON, Flávio. Novo CPC: Fundamentos e sistematização. 3. ed. rev., atual. e ampl. Rio de Janeiro: Forense, 2016. p. 115).

45 NUNES, Dierle; SILVA, Natanael Lud Santos; PEDRON, Flávio Quinaud. Desconfiando da imparcialidade dos sujeitos processuais: um estudo sobre os vieses cognitivos, a mitigação de seus efeitos e o debiasing. Salvador: Juspodivm, 2018. p. 49.

46 NUNES, Dierle; SILVA, Natanael Lud Santos; PEDRON, Flávio Quinaud. Desconfiando da imparcialidade dos sujeitos processuais: um estudo sobre os vieses cognitivos, a mitigação de seus efeitos e o debiasing. Salvador: Juspodivm, 2018. p. 49-50.

${ }^{47}$ SILVA, Natanael Lud. Os vieses de cognição e o processo jurisdicional democrático: um estudo sobre a mitigação de seus efeitos e o debiasing. 128f. 2018. Dissertação (Mestrado em Direito) - Pontifícia Universidade Católica de Minas Gerais, Belo Horizonte, 2018. p. 44-69. Acesso: 12/10/2019.

${ }^{48} \mathrm{Na}$ análise da responsabilidade civil, por exemplo, o viés de retrospectiva "pode atuar dificultando que o julgador reconheça a inexistência de culpa quando conhecido o resultado danoso, havendo, portanto, uma distorção quanto à interpretação do caso concreto." (SILVA, Natanael Lud. Os vieses de cognição e o processo jurisdicional democrático: um estudo sobre a mitigação de seus efeitos e o debiasing. 128f. 2018. Dissertação (Mestrado em Direito) - Pontifícia Universidade Católica de Minas Gerais, Belo Horizonte, 2018. p. 57). Acesso: 12/10/2019. 
ajustamento, em virtude do qual assume-se uma âncora ${ }^{49}$, geralmente aleatória, e busca-se elementos para se ajustar a ela; e) viés de status quo, caracterizado pela tendência de confirmação de uma decisão ou posição já existente; f) viés de aversão à perda, o qual, no âmbito jurídico, significa a supressão do dissenso por medo da perda, por exemplo, ao proferir um voto minoritário.

Diante da constatação de que tais interferências externas ao direito tornam as decisões judiciais ilegítimas ${ }^{50}$ — posto que ao poder judiciário cabe aplicar o direito ao caso concreto, observando os princípios e garantias constitucionais, como o devido processo legal, que não admite a ação demasiada de vieses cognitivos sobre o julgador ${ }^{51}$ o princípio da colegialidade aparece como importante mecanismo de implementação dos princípios da imparcialidade e do contraditório como garantia de influência e não surpresa. Para tanto, é necessário entender a imparcialidade do órgão decisor além da necessidade de que ele não tenha nenhum interesse no feito ou vínculo com as partes. Assim, a imparcialidade também deve existir em relação à tentativa de, ao menos, ampliar o distanciamento entre a motivação da decisão e as questões subjetivas do julgador, as quais englobam suas experiências pessoais e preconceitos ${ }^{52}$.

Neste cenário, tendo em vista a constatação de que a fase instrutória do processo, mesmo que estabelecida de modo comparticipativo, não pode, em alguns casos, por si só, afastar a interferência dos vieses cognitivos sobre o julgador; Silva ${ }^{53}$ conclui que a colegialidade tem a primordial função de mitigar a interferência destes fatores externos no

\footnotetext{
${ }^{49}$ Podem funcionar como âncoras "o valor concedido à causa, ou ao pedido de indenização por danos morais, o tempo de prisão pedido pelo Ministério Público, ou mesmo o contato com provas ilícitas [...]" (SILVA, Natanael Lud. Os vieses de cognição e o processo jurisdicional democrático: um estudo sobre a mitigação de seus efeitos e o debiasing. 128f. 2018. Dissertação (Mestrado em Direito) - Pontifícia Universidade Católica de Minas Gerais, Belo Horizonte, 2018. p. 62-63). Acesso: 12/10/2019.

50 NUNES, Dierle; SILVA, Natanael Lud Santos; PEDRON, Flávio Quinaud. Desconfiando da imparcialidade dos sujeitos processuais: um estudo sobre os vieses cognitivos, a mitigação de seus efeitos e o debiasing. Salvador: Juspodivm, 2018. p. 47.

${ }^{51}$ SILVA, Natanael Lud. Os vieses de cognição e o processo jurisdicional democrático: um estudo sobre a mitigação de seus efeitos e o debiasing. 128f. 2018. Dissertação (Mestrado em Direito) - Pontifícia Universidade Católica de Minas Gerais, Belo Horizonte, 2018. p. 55. Acesso: 12/10/2019.

52 A respeito da impossibilidade de se obter totalmente a imparcialidade do julgador, Theodoro Junior; Nunes; Bahia e Pedron, apontam que "O mito da imparcialidade (neutralidade) como blindagem ao elemento anímico do juiz faz crer no seu desinteresse no julgamento, de modo absoluto, conduzindo ao desprezo de suas pré-compreensões e propensões cognitivas solitárias no ato de julgar." (THEODORO JUNIOR, Humberto; NUNES, Dierle; BAHIA, Alexandre; PEDRON, Flávio. Novo CPC: Fundamentos $e$ sistematização. 3. ed. rev., atual. e ampl. Rio de Janeiro: Forense, 2016. p. 115)

${ }^{53}$ SILVA, Natanael Lud. Os vieses de cognição e o processo jurisdicional democrático: um estudo sobre a mitigação de seus efeitos e o debiasing. 128f. 2018. Dissertação (Mestrado em Direito) - Pontifícia Universidade Católica de Minas Gerais, Belo Horizonte, 2018. p. 109-125. Acesso: 12/10/2019.
} 
provimento judicial, por meio do exercício do contraditório como garantia de influência na decisão, que será formada mediante consistente discussão entre os julgadores e entre eles e as partes.

Portanto, observa-se que o julgamento colegiado reduz a interferência de vieses cognitivos advindos de um único julgador, pois na análise pluripessoal dificilmente uma decisão eivada de preconcepções prevaleceria ${ }^{54}$. Destarte, é possível afirmar que a colegialidade atua como uma tentativa de garantir a imparcialidade do julgador, inerente à "própria jurisdição no Estado Democrático de Direito" ${ }^{55}$. Isto porque, se no processo judicial o órgão julgador é parcial, o processo não é democrático, pois, não permite a formação da decisão de forma comparticipativa, vez que a parcialidade do magistrado veda o direito de influência das partes.

\subsection{O princípio da colegialidade e o modelo democrático de processo}

O processo democrático pressupõe a participação relevante de todos os sujeitos, os quais devem contribuir para o discurso e, consequentemente, para a formação do provimento final. Sendo assim, no julgamento colegiado, o acórdão deve ser formado pela participação de todos os julgadores, sem que o voto proferido por um deles figure em posição de maior relevância em relação aos demais. A este respeito, Carvalho ensina que "o pronunciamento do órgão colegiado, diferentemente do singular, forma-se progressivamente, de acordo com as manifestações de cada juiz que participa do julgamento" $" 56$.

Com efeito, no modelo democrático e participativo de processo não é possível "privilegiar nenhum dos sujeitos processuais" $" 57$ em detrimento dos demais, motivo pelo

\footnotetext{
${ }^{54}$ De acordo com Chaves: "a deliberação colegiada atua de forma contrafática, objetivando coibir as propensões cognitivas do julgador, por meio da discursividade entre os sujeitos processuais." (CHAVES, Jéssica Galvão. Princípio constitucional da colegialidade na formação da decisão pluripessoal. 154f. 2017. Dissertação (Mestrado em Direito) - Pontifícia Universidade Católica de Minas Gerais, Belo Horizonte, 2017. p. 135). Acesso: 13/10/2019.

${ }^{55}$ SILVA, Natanael Lud. Os vieses de cognição e o processo jurisdicional democrático: um estudo sobre a mitigação de seus efeitos e o debiasing. 128f. 2018. Dissertação (Mestrado em Direito) - Pontifícia Universidade Católica de Minas Gerais, Belo Horizonte, 2018. p. 82. Acesso: 12/10/2019.

${ }^{56}$ CARVALHO, Fabiano. Poderes do Relator nos Recursos: Art. 557 do CPC - Col. Theotonio Negrão. São Paulo: Saraiva, 2008. p. 03.

57 NUNES, Dierle José Coelho. Direito Constitucional ao Recurso: Da teoria geral dos recursos, das reformas processuais e da comparticipação nas decisões. Rio de Janeiro: Lumen Juris, 2006. p. 142. Acesso: $17 / 10 / 2019$.
} 
qual aplica-se o modelo policêntrico também no julgamento colegiado. Embora no julgamento colegiado todos os julgadores componham o mesmo sujeito processual, qual seja, o Estado-Juiz, certo é que internamente este sujeito é composto por mais de um indivíduo. Nota-se que essa formação pluripessoal, quando observado o diálogo entre os julgadores, é a responsável por conferir maior legitimidade e correção à decisão. Isso porque, no julgamento colegiado, os julgadores se manifestam a respeito das mesmas questões a fim de obter a solução mais adequada para o caso em análise. Conforme preleciona Carvalho, "o pronunciamento do órgão colegiado, marcado pela mesma natureza e objeto, é ato composto, porque se forma pela co-participação de mais de um integrante do órgão, em momentos sucessivos" 58.

Dessarte, a elaboração do relatório contribui para o exercício proveitoso da colegialidade como garantidora do processo jurisdicional democrático, uma vez que o relatório delimitará toda a matéria relevante para ser levada ao discurso, apresentando às partes e aos demais juízes as matérias controvertidas sobre as quais se assentam a deliberação. O relatório, nesta perspectiva, cumpre duas finalidades. A primeira é o exercício do contraditório como garantia de influência e não surpresa, por expor de forma sintética toda a matéria que demanda discussão ${ }^{59}$. A segunda é o desenvolvimento célere e aprofundado do debate, na medida em que propicia o foco nas questões relevantes.

Neste ponto, facilitada a detecção das questões controvertidas pelo relatório, é necessário que cada julgador apresente os fundamentos que levam a conclusão final de seu voto, de forma a exercer o diálogo propiciado pela colegialidade. Assim, o julgador deve buscar o afastamento de vieses de cognição que o prenda ao voto dos demais, como o viés da aversão à perda. Isto porque, a dissidência interpretativa também apresenta relevante papel na construção de resultados mais responsáveis ${ }^{60}$. Aqui não se defende a formação de

\footnotetext{
${ }^{58}$ CARVALHO, Fabiano. Poderes do Relator nos Recursos: Art. 557 do CPC - Col. Theotonio Negrão. São Paulo: Saraiva, 2008. p. 04.

${ }^{59}$ CHAVES, Jéssica Galvão. Princípio constitucional da colegialidade na formação da decisão pluripessoal. 154f. 2017. Dissertação (Mestrado em Direito) - Pontifícia Universidade Católica de Minas Gerais, Belo Horizonte, 2017. p. 139. Acesso: 13/10/2019.

${ }^{60}$ SILVA, Natanael Lud. Os vieses de cognição e o processo jurisdicional democrático: um estudo sobre a mitigação de seus efeitos e o debiasing. 128f. 2018. Dissertação (Mestrado em Direito) - Pontifícia Universidade Católica de Minas Gerais, Belo Horizonte, 2018. p. 120. Acesso: 12/10/2019.
} 
decisões plurais ${ }^{61}$, na medida em que todos os julgadores deliberarão a respeito dos mesmos pontos controvertidos.

Desse modo, o princípio da colegialidade, em toda sua amplitude, demanda que seja estabelecido um diálogo entre os integrantes do órgão colegiado, bem como entre eles e as partes, a fim de que os fundamentos expostos por cada um deles contribua para o alcance da decisão mais justa ${ }^{62}$. Diante disso, a colegialidade meramente formal — isto é, aquela que observa apenas a forma, desprezando o exercício do diálogo entre os julgadores, na medida em que, muitas vezes, os vogais se limitam a concordar com o relator $^{63}$ sem analisar detidamente todas as questões colocadas em pauta ${ }^{64}$ - deturpa a finalidade do princípio da colegialidade no âmbito do processo judicial democrático. Esta prática torna-se evidente ao constatar-se a incongruência entre o fundamento dos votos proferidos pelo mesmo julgador, no julgamento de casos idênticos, pois, o julgador, quando exercendo a função de relator, apresenta fundamentação discrepante daquela com a qual concordou no exercício da função de vogal ${ }^{65}$.

\section{A DECISÃO MONOCRÁTICA PROFERIDA NO SUPERIOR TRIBUNAL DE JUSTIÇA E A FUNÇÃO DO CABIMENTO DO AGRAVO INTERNO E DO AGRAVO REGIMENTAL CONTRA ESTA DECISÃO}

\footnotetext{
${ }^{61}$ Decisão plural é aquela em que "cada julgador atua de forma solitária, solipsista, não formando uma decisão colegiada, mas um somatório de decisões individuais, sem deliberação, diálogo, entre os membros do colégio e as partes, sobre a identidade do arcabouço argumentativo posto em julgamento". (CHAVES, Jéssica Galvão. Princípio constitucional da colegialidade na formação da decisão pluripessoal. 154f. 2017. Dissertação (Mestrado em Direito) - Pontifícia Universidade Católica de Minas Gerais, Belo Horizonte, 2017. p. 37). Acesso: 13/10/2019.

${ }^{62}$ Sobre isso CHAVES assevera que: "a compreensão do princípio constitucional da colegialidade repeli a possibilidade da decisão pluripessoal ser fruto da atuação solitária de um julgador, sem deliberação com seus pares e com as partes" (CHAVES, Jéssica Galvão. Princípio constitucional da colegialidade na formação da decisão pluripessoal. 154f. 2017. Dissertação (Mestrado em Direito) - Pontifícia Universidade Católica de Minas Gerais, Belo Horizonte, 2017. p. 140). Acesso: 13/10/2019.

${ }^{63}$ A concordância do vogal com o relator, sem que o primeiro analise a questão posta em debate, pode ser considerada uma manifestação do viés de ancoragem e ajustamento (COSTA, Eduardo José da Fonseca. Levando a imparcialidade a sério: proposta de um modelo interseccional entre direito processual, economia e psicologia. 187f. 2016. Tese (Doutorado em Direito Processual Civil) - Pontifícia Universidade Católica de São Paulo, São Paulo, 2016. p. 111-112). Acesso: 18/11/2019.

${ }^{64}$ NUNES, Dierle; DELFINO, Lúcio. Novo CPC: Enunciados de súmula e pseudo colegialidade. Justificando, São Paulo, 28 ago. 2014. s.p. Acesso: 14/10/2019.

${ }^{65}$ CHAVES, Jéssica Galvão. Princípio constitucional da colegialidade na formação da decisão pluripessoal. 154f. 2017. Dissertação (Mestrado em Direito) - Pontifícia Universidade Católica de Minas Gerais, Belo Horizonte, 2017. p. 32. Acesso: 13/10/2019.
} 
O relator possui considerável rol de atribuições na tramitação dos processos nos tribunais, podendo, inclusive, proferir decisões monocráticas. Em suma, a maioria das atribuições do relator estão concentradas no art. 932 do Código de Processo Civil (CPC) e podem ser classificadas como poderes de gestão ou de decisão ${ }^{66}$, de acordo com a sua natureza.

Dentre as funções de gestão processual incluem-se a instrução, a direção e a ordenação do processo, a exemplo do que dispõe o art. 932, inciso I, do CPC. Por sua vez, os poderes de decisão ${ }^{67}$ atribuem ao relator a função de, isoladamente, homologar a autocomposição das partes; analisar o requerimento de concessão de tutela provisória; negar conhecimento a recurso que não atende os requisitos de admissibilidade, tenha sido prejudicado ou que não impugne especificamente os fundamentos da decisão recorrida; decidir o incidente de desconsideração de personalidade jurídica, se instaurado originariamente perante o tribunal; nos termos do art. 932, incisos I, II, III e VI do CPC. Ademais, de acordo com o art. 932, incisos IV e V do CPC, o relator também terá poderes para decidir monocraticamente o mérito do recurso:

Art. 932. Incumbe ao relator:

[...] IV - negar provimento a recurso que for contrário a:

a) súmula do Supremo Tribunal Federal, do Superior Tribunal de Justiça ou do próprio tribunal;

b) acórdão proferido pelo Supremo Tribunal Federal ou pelo Superior Tribunal de Justiça em julgamento de recursos repetitivos;

c) entendimento firmado em incidente de resolução de demandas repetitivas ou de assunção de competência;

$\mathrm{V}$ - depois de facultada a apresentação de contrarrazões, dar provimento ao recurso se a decisão recorrida for contrária a:

a) súmula do Supremo Tribunal Federal, do Superior Tribunal de Justiça ou do próprio tribunal;

b) acórdão proferido pelo Supremo Tribunal Federal ou pelo Superior Tribunal de Justiça em julgamento de recursos repetitivos;

c) entendimento firmado em incidente de resolução de demandas repetitivas ou de assunção de competência; $\left[\ldots{ }^{68}\right.$

Importante acrescentar que, nos termos do art. 932, inciso VII do CPC, o regimento interno dos tribunais pode atribuir outras funções ao relator, além das já previstas nos

\footnotetext{
${ }^{66}$ THEODORO JUNIOR, Humberto. Curso de Direito Processual Civil. 50 ed. rev., atual., e ampl. Rio de Janeiro: Forense, 2017. V. 3. p. 956-957.

${ }^{67}$ DIDIER JR., Fredie; CUNHA, Leonardo Carneiro da. Curso de direito processual civil: o processo civil nos tribunais, recursos, ações de competência originária de tribunal e querela nullitatis, incidentes de competência originária de tribunal. 13. ed. Salvador: Juspodivm, 2016. V. 3. p. 50.

${ }^{68}$ BRASIL. [Código de Processo Civil]. Lei no 13.105, de 16 de março de 2015. Código de Processo Civil. Diário Oficial da União, Brasília, 17 mar. 2015. Acesso: 14/10/2019.
} 
dispositivos supracitados. As atribuições do relator no STJ estão disciplinadas no art. 34 do Regimento Interno do Superior Tribunal de Justiça (RISTJ) ${ }^{69}$.

Salienta-se que o RISTJ atribui ao presidente do STJ, antes da distribuição do recurso, poderes semelhantes aos conferidos ao relator pelo art. 932 do CPC. Assim, o presidente possui atribuições que englobam desde a análise do pedido de desistência ou homologação da autocomposição, até a análise dos requisitos de admissibilidade e o julgamento do mérito dos recursos, nas hipóteses do art. 21-E, incisos I a IX, do RISTJ. Estas atribuições são delegáveis ao vice-presidente e aos presidentes das seções, por autorização do $\S 3^{\circ}$ do art. 21-E do RISTJ.

Vale mencionar, ainda, que compete ao presidente do STJ a apreciação das revisões criminais e dos habeas corpus, quando manifestamente inadmissíveis por incompetência, caso em que remeterá os autos ao órgão que julgar competente. Além disso, nos termos do art. 313, inciso II, do RISTJ, o presidente pode arquivar o pedido de intervenção federal, quando manifestamente infundado. Também compete ao presidente decidir o incidente de suspensão de segurança, de liminar e de sentença, cuja decisão foi proferida em face do Poder Público, nas hipóteses do art. 271 do RISTJ.

Diante do exposto acima, denota-se que o relator e o presidente do tribunal, de fato, possuem acentuado número de atribuições em detrimento de seus pares. No Brasil, o aumento dos poderes conferidos ao relator e ao presidente dos tribunais foi justificado pela necessidade de diminuir a sobrecarga do Poder Judiciário ${ }^{70}$, em face do aumento contínuo do volume de demandas em tramitação perante os tribunais. O pressuposto de validade dessa medida é a possibilidade de análise da decisão monocrática pelo órgão colegiado, a fim de prestigiar o princípio da colegialidade. Por isso, contra as decisões monocráticas proferidas nos tribunais são cabíveis os recursos de agravo interno e de agravo regimental.

O agravo interno, nos termos do art. 1.021 do CPC, é o recurso cabível contra decisão monocrática proferida pelo relator e o prazo para sua interposição é de 15 (quinze) dias, conforme a regra prevista $\S 5^{\circ}$, do art. 1.003 do CPC. Ao receber o agravo interno, o relator pode exercer a retratação, conforme o art. $1.021, \S 2^{\circ}$, do CPC. Caso não haja

\footnotetext{
${ }^{69}$ BRASIL. Regimento Interno. Brasília: Superior Tribunal de Justiça, 2019. Acesso: 18/11/2019.

${ }^{70}$ CARVALHO, Fabiano. Poderes do Relator nos Recursos: Art. 557 do CPC - Col. Theotonio Negrão. São Paulo: Saraiva, 2008. p. 14.
} 
retratação, o julgamento do agravo interno é realizado pelo órgão colegiado ao qual o relator se encontra vinculado.

Além disso, quando o agravo interno for julgado improcedente ou não conhecido por votação unânime do órgão colegiado, este poderá, fundamentadamente, declarar o recurso manifestamente inadmissível ou improcedente e condenar o agravante ao pagamento de multa, cujo valor será fixado entre um e cinco por cento do valor da causa atualizado, nos termos do $\S 4^{\circ}$ do art. 1.021 do CPC. A imposição desta multa tem como fundamento exercer coerção e evitar a prática de atos que violam o dever de cooperação entre os sujeitos, a economia, a celeridade e a boa-fé processual. Assim, pode ser considerada uma decorrência da imposição de sansão contra a litigância de má-fé e $^{71}$ condiciona a interposição de qualquer outro recurso ao pagamento da multa fixada, de acordo com o $\S 5^{\circ}$ do art. 1.021 do CPC.

Ademais, considerando que o presidente do STJ também possui poderes para proferir decisões monocráticas, o agravo interno igualmente é cabível contra sua decisão, nos termos do $\S 2^{\circ}$ do art. 21-E do RISTJ. Após interposto o recurso contra a decisão do presidente do STJ, caso este não exerça a retratação, os autos serão distribuídos para a turma ou seção competente. Assim, em regra, o prolator da decisão recorrida não participa da análise do recurso, posto que o presidente profere a decisão monocrática antes da distribuição do recurso. Contra as decisões monocráticas proferidas no STJ pelo presidente do Tribunal, pelo presidente da Corte Especial, pelo presidente de Seção, pelo presidente de Turma ou pelo relator, também é cabível o agravo regimental ${ }^{72}$, conforme artigos 258 ; 271, §2º 284 e 313, inciso II do RISTJ.

No contexto do processo judicial democrático, a interposição de recurso para o órgão colegiado contra a decisão monocrática proferida nos tribunais, visa a observância ao

\footnotetext{
${ }^{71}$ MEDINA, José Miguel Garcia. Curso de Direito Processual Civil Moderno. 3. ed. rev., atual. e ampl. São Paulo: Revista dos Tribunais, 2017. p. 1.272.

${ }^{72}$ A origem do agravo regimental se ampara na da Lei n. 8.038 de 1990, em seu art. 39: "Da decisão do presidente do Tribunal, de Seção, de Turma ou de Relator que causar gravame à parte, caberá agravo para o órgão especial, Seção ou Turma, conforme o caso, no prazo de cinco dias" (BRASIL. Lei no 8.038, de 28 de maio de 1990. Institui normas procedimentais para os processos que especifica, perante o Superior Tribunal de Justiça e o Supremo Tribunal Federal. Diário Oficial da União, Brasília, 29 maio 1990). Acesso: 25/11/2019.
} 
princípio da colegialidade. Neste sentido, Silva ${ }^{73}$, com base em Nunes ${ }^{74}$, afirma que o agravo interno exerce a função contrafática ${ }^{75}$ de "controle intersubjetivo contra o individualismo e subjetivismo" das decisões monocráticas proferidas pelo relator ou presidente do tribunal. Esse subjetivismo e individualismo das decisões monocráticas apresenta-se como um entrave ao princípio do contraditório, em sua perspectiva de garantia de influência nas decisões judiciais.

Neste cenário, destaca-se que o CPC, no $\S 3^{\circ}$ do art. 1.021 , veda que o relator se limite a reproduzir "os fundamentos da decisão agravada para julgar improcedente o agravo interno"76. Este dispositivo contribui para o respeito do contraditório como garantia de influência no julgamento do agravo interno, uma vez que impõe ao julgador o dever de analisar os argumentos suscitados pela parte contra a decisão recorrida.

No entanto, diante da necessidade de neutralizar ou, ao menos, reduzir a interferência de vieses cognitivos na formação da decisão judicial, $\operatorname{Costa}^{77}$ apresenta tese sobre a impropriedade do relator participar do julgamento do agravo interno ${ }^{78}$. Isto porque, o relator estaria contaminado pelas razões que o levaram a inadmitir ou negar provimento ao recurso na decisão monocrática, tendo sua imparcialidade afetada sobremaneira pela ação do viés de confirmação em conjunto com o viés de trancamento. Contudo, persistindo a presença do relator na análise do recurso de agravo interno, a sustentação oral teria o

\footnotetext{
${ }^{73}$ SILVA, Natanael Lud. Os vieses de cognição e o processo jurisdicional democrático: um estudo sobre a mitigação de seus efeitos e o debiasing. 128f. 2018. Dissertação (Mestrado em Direito) - Pontifícia Universidade Católica de Minas Gerais, Belo Horizonte, 2018. p. 116. Acesso: 12/10/2019.

${ }^{74}$ NUNES, Dierle José Coelho. Colegialidade das decisões dos Tribunais - Sua Visualização como Princípio Constitucional e do Cabimento de Interposição de Agravo Interno de Todas as Decisões Monocráticas do Relator. Revista IOB de Direito Processual Civil, Brasília, v. 9, n 50, p. 50-61, nov./dez. 2007. p. 53.

${ }^{75} \mathrm{~A}$ função contrafática do direito pode ser definida como sua finalidade de reprimir comportamentos sociais considerados impróprios. No âmbito no CPC, é possível afirmar que sua postura contrafática visa a implementação da "efetividade e garantia de nosso modelo constitucional de processo", contrapondo tendências anteriores como o privilégio da forma em detrimento do mérito e o apreço pela quantidade em prejuízo da qualidade das decisões (NUNES, Dierle José. A função contrafática do Direito e Novo CPC. Revista do Advogado, São Paulo, v. 35, no 126, p. 51-55, maio 2015. p. 51-52). Acesso: 18/11/2019.

${ }^{76}$ BRASIL. [Código de Processo Civil]. Lei no 13.105 , de 16 de março de 2015. Código de Processo Civil. Diário Oficial da União, Brasília, 17 mar. 2015. Acesso: 14/10/2019.

77 COSTA, Eduardo José da Fonseca. Levando a imparcialidade a sério: proposta de um modelo interseccional entre direito processual, economia e psicologia. 187f. 2016. Tese (Doutorado em Direito Processual Civil) - Pontifícia Universidade Católica de São Paulo, São Paulo, 2016. p. 118-142. Acesso: $18 / 11 / 2019$.

${ }^{78}$ Neste ponto, cumpre mencionar que a legislação processual, ainda que discretamente, reconhece que o prolator da decisão que se pretende modificação não deveria participar do julgamento da ação ou do recurso interposto contra tal decisão. É o que se verifica da diç̧ão do parágrafo único do art. 971 do CPC, o qual recomenda que o relator da ação rescisória não seja escolhido entre os juízes que participaram da decisão rescindenda.
} 
condão de possibilitar o amplo exercício do contraditório como garantia de influência na decisão judicial. De fato, o debate oral pode propiciar um ambiente favorável para que os julgadores percebam as razões substanciais invocadas pelas partes. Sobre a eficácia da sustentação oral Silva ${ }^{79}$, salienta que:

Há casos em que os julgadores podem estar completamente enviesados por circunstâncias do caso, pelas decisões anteriormente proferidas ou mesmo pela padronização decisória existente para casos análogos. Nesse cenário, não há alternativas para os patronos das partes, a não ser a insistência no debiasing pela via da apresentação de memorais, despachos presenciais junto aos magistrados e proferimento de sustentação oral em sessão de julgamento com o fim de individualização dos casos e explicitação de circunstâncias fático-jurídicas relevantes para o deslinde da controvérsia, incorporando-se o exercício do contraditório como influência das partes sobre o julgamento.

Nota-se que o CPC de 2015, no art. 937, inciso VIII, previa a sustentação oral também para o "agravo interno originário de recurso de apelação, de recurso ordinário, de recurso especial ou de recurso extraordinário" ${ }^{" 80}$. No entanto, o referido dispositivo foi objeto de veto presidencial, sob o fundamento de que "a previsão de sustentação oral para todos os casos de agravo interno resultaria em perda de celeridade processual, princípio norteador do novo Código, provocando ainda sobrecarga nos Tribunais"81. Assim, a sustentação oral, conforme o $\$ 3^{\circ}$ do art. 937 do $\mathrm{CPC}$, subsistiu apenas para o agravo interno interposto contra decisão do relator que extingue a ação rescisória, a reclamação e o mandado de segurança, processos de competência originária dos tribunais.

\section{O PRINCÍPIO DA COLEGIALIDADE NO SUPERIOR TRIBUNAL DE JUSTIÇA}

Diante do exposto, inicia-se a investigação acerca do respeito ao princípio da colegialidade pelo STJ. Analisando o Boletim Estatístico do $\mathrm{STJ}^{82}$, percebe-se que o número de decisões monocráticas proferidas no julgamento dos processos que tramitam

\footnotetext{
${ }^{79}$ SILVA, Natanael Lud. Os vieses de cognição e o processo jurisdicional democrático: um estudo sobre a mitigação de seus efeitos e o debiasing. 128f. 2018. Dissertação (Mestrado em Direito) - Pontifícia Universidade Católica de Minas Gerais, Belo Horizonte, 2018. p. 118. Acesso: 12/10/2019.

${ }^{80}$ BRASIL. [Código de Processo Civil]. Lei no 13.105, de 16 de março de 2015. Código de Processo Civil. Diário Oficial da União, Brasília, 17 mar. 2015. Acesso: 14/10/2019.

${ }^{81}$ BRASIL. Mensagem n ${ }^{\circ}$ 56, de 16 de março de 2015. Diário Oficial da União, Brasília, 17 mar. 2015. Acesso: 18/11/2015.

${ }^{82}$ BRASIL. Assessoria de Modernização e Gestão Estratégica Coordenadoria de Gestão da Informação. Boletim estatístico: agosto 2019. Brasília: Superior Tribunal de Justiça, 2019. p. 29. Acesso: 14/10/2019.
} 
perante o STJ supera, aproximadamente, quatro vezes o número de decisões colegiadas, conforme o gráfico $1^{83}$.

A priori, tal constatação não violaria o princípio da colegialidade, na medida em que é facultado à parte prejudicada interpor o recurso de agravo interno ou agravo regimental, levando a questão para apreciação do órgão colegiado. A propósito, essa é a justificativa apresentada pelo próprio STJ para negar a possível ofensa ao princípio da colegialidade.

Devido ao alto índice de decisões monocráticas proferidas no STJ, o número de agravos regimentais e os agravos internos interpostos de janeiro a agosto de 2019 alcança o total de 54.551 (cinquenta e quatro mil, quinhentos e cinquenta e um) ${ }^{84}$. À vista disso, realizou-se uma pesquisa de jurisprudência, no sítio eletrônico do STJ, a fim de averiguar, por amostragem, o índice de provimento dos agravos internos e dos agravos regimentais interpostos perante o STJ, no período de 01 de janeiro de 2019 a 31 de agosto de $2019^{85}$. Por meio da referida pesquisa, verificou-se que apenas 3\% (três por cento) dos recursos interpostos contra as decisões monocráticas foram providos ou parcialmente providos, conforme o gráfico 2.

Soma-se a isso, a constatação de que os recursos providos ou parcialmente providos não tiveram o condão de alterar substancialmente as decisões monocráticas. Deveras, dentre os 16 (dezesseis) recursos providos ou parcialmente providos ${ }^{86}: 5$ (cinco) foram parcialmente providos, sendo que 4 (quatro) destes apenas para alterar os honorários advocatícios fixados ou analisar o requerimento de justiça gratuita; 4 (quatro) foram providos para realizar juízo de admissibilidade negativo, não conhecendo recurso do especial.

Além disso, observou-se que, do total de 440 (quatrocentos e quarenta) recursos analisados, em apenas 3 (três), isto é, $1 \%$ (um por cento), o julgamento colegiado alterou o entendimento explanado pelo relator em seu voto, é o que se infere do gráfico 3.

\footnotetext{
${ }^{83}$ Os gráficos estão na lista pertinente, ao final do artigo, segundo normalização da revista.

${ }^{84}$ BRASIL. Assessoria de Modernização e Gestão Estratégica Coordenadoria de Gestão da Informação. Boletim estatístico: agosto 2019. Brasília: Superior Tribunal de Justiça, 2019. p. 37. Acesso: 14/10/2019.

85 Vide: anexo A, contendo a metodologia da pesquisa realizada, e anexo B, contendo a tabela elaborada a partir do resultado da pesquisa, ambos os anexos encontram-se no documento suplementar.

${ }^{86}$ Vide: tabela II, inserida no anexo C, contido no documento suplementar.
} 
Ademais, também se verificou que os órgãos colegiados do STJ não conheceram ou negaram provimento aos recursos de agravo interno ou agravo regimental por unanimidade em 97\% (noventa e sete por cento) dos recursos julgados, de acordo com o gráfico 4.

Porém, em um universo de 413 (quatrocentos e treze) recursos julgados improvidos ou não conhecidos por unanimidade, apenas 6 (seis) deles, ou seja, aproximadamente $1 \%$ (um por cento), foram considerados manifestamente improcedentes ou inadmissíveis, ensejando a aplicação da multa prevista no $\S 4^{\circ}$ do art. 1.021 do CPC.

Realmente, é uma tarefa quase impossível às partes reverter o resultado do julgamento monocrático ou do posicionamento do relator do STJ. Embora a maior parte dos agravos regimentais e agravos internos interpostos no STJ não sejam manifestamente improcedentes ou inadmissíveis, não há espaço para que o debate abra divergência entre os julgadores, posto que, em regra, os vogais simplesmente concordam com o relator. Isto porque, o relator foi vencido em apenas $1 \%$ (um por cento) dos casos levados para a apreciação do órgão colegiado.

\subsection{O conflito entre o princípio da duração razoável do processo e o princípio da colegialidade no Superior Tribunal de Justiça}

Já há algum tempo se estabeleceu um debate acerca da necessidade de se efetivar o princípio da duração razoável do processo, em que pese o elevado volume de feitos que tramitam perante os órgãos do poder judiciário. No STJ, o cenário não é diferente, somente no período de janeiro a agosto de 2019 foram recebidos 258.912 (duzentos e cinquenta e oito mil, novecentos e doze) processos novos, número que representa cerca de 1.638 (um mil, seiscentos e trinta e oito) casos novos a cada dia útil ${ }^{87}$. A taxa de congestionamento ${ }^{88}$ no STJ - embora apresente crescente redução se comparada ao ano de 2015, quando chegou a 53\% (cinquenta e três por cento) - no ano de 2019, alcança 42,5\% (quarenta e dois e meio por cento).

\footnotetext{
87 BRASIL. Assessoria de Modernização e Gestão Estratégica Coordenadoria de Gestão da Informação. Boletim estatístico: agosto 2019. Brasília: Superior Tribunal de Justiça, 2019. p. 6. Acesso: 14/10/2019.

${ }^{88}$ A taxa de congestionamento "mede o índice de processos baixados em relação ao total de processos a serem julgados e ao total de processos recebidos." (BRASIL. Superior Tribunal de Justiça. Plano STJ 2020: a base para o futuro que queremos. 3. ed. rev. e atual. Brasília: Superior Tribunal de Justiça, 2018. p. 24). Acesso: 17/10/2019.
} 
Neste contexto, ao elaborar o plano estratégico para 2020, o STJ identificou como um dos empecilhos à sua atuação o volume excessivo de processos, o que potencialmente pode tornar as decisões morosas ${ }^{89}$. Assim, um dos objetivos elencados no projeto foi monitorar demandas repetitivas, bem como de grandes litigantes, a fim de combater a "cultura da excessiva judicialização"90. Tudo isso, objetivando "uma justiça célere e efetiva"91.

Com efeito, a "lentidão do Poder Judiciário na resolução de conflitos gera flagrantes inseguranças jurídicas e injustiças intra e intergeracionais, vez que o jurisdicionado passa a não mais acreditar no modelo jurisdicional monopolizado pelo Estado" 92 . Sendo assim, no Estado Democrático de Direito, o enfretamento à morosidade da tutela jurisdicional não pode ser adiado, sob pena de violar o amplo acesso à jurisdição e não concretizar o ideal de processo justo ${ }^{93}$, obtido mediante a observância do devido processo legal. Isso prejudica a implementação da sustentabilidade em sua dimensão jurídico-política, que visa a efetivação de direitos fundamentais, como a duração razoável do processo e o amplo acesso à jurisdição, visando assegurar a continuidade da vida e o bem-estar da presente e das futuras gerações ${ }^{94}$.

Diante disso, foram adotadas medidas para reduzir o acervo de processos dos tribunais, dentre as quais o aumento dos poderes do relator ${ }^{95}$ e do presidente, dando-lhes

\footnotetext{
${ }^{89}$ BRASIL. Superior Tribunal de Justiça. Plano STJ 2020: a base para o futuro que queremos. 3. ed. rev. e atual. Brasília: Superior Tribunal de Justiça, 2018. p. 9. Acesso: 17/10/2019.

${ }^{90}$ BRASIL. Superior Tribunal de Justiça. Plano STJ 2020: a base para o futuro que queremos. 3. ed. rev. e atual. Brasília: Superior Tribunal de Justiça, 2018. p. 15. Acesso: 17/10/2019.

${ }^{91}$ BRASIL. Superior Tribunal de Justiça. Plano STJ 2020: a base para o futuro que queremos. 3. ed. rev. e atual. Brasília: Superior Tribunal de Justiça, 2018. p. 28. Acesso: 17/10/2019.

${ }^{92}$ GOMES, Magno Federici; FERREIRA, Leandro José. A dimensão jurídico-política da sustentabilidade e o direito fundamental à razoável duração do procedimento. Revista do Direito, Santa Cruz do Sul, v. 2, n ${ }^{\circ} 52$, p. 93-111, maio/set. 2017. p. 107. Acesso: 28/08/2019.

${ }^{93}$ GOMES, Magno Federici; FERREIRA, Leandro José. A dimensão jurídico-política da sustentabilidade e o direito fundamental à razoável duração do procedimento. Revista do Direito, Santa Cruz do Sul, v. 2, no 52 , p. 93-111, maio/set. 2017. p. 108. Acesso: 28/08/2019.

${ }^{94}$ GOMES, Magno Federici; FERREIRA, Leandro José. A dimensão jurídico-política da sustentabilidade e o direito fundamental à razoável duração do procedimento. Revista do Direito, Santa Cruz do Sul, v. 2, $\mathrm{n}^{\circ} 52$, p. 93-111, maio/set. 2017. p.110. Acesso: 28/08/2019.

${ }_{95}$ VEREA, Larissa. O aumento dos poderes do relator e o julgamento monocrático dos recursos cíveis. $187 \mathrm{f}$. 2014. Dissertação (Mestrado em Direito) - Faculdade de Direito da Universidade de São Paulo, São Paulo, 2014. p. 15-17. Acesso: 13/10/2019.
} 
atribuição, inclusive, para inadmitir ou julgar o mérito dos recursos. Sobre isso, Nunes ${ }^{96}$ assevera que:

[...] apesar da inerente colegialidade de análise de recursos, o sistema normativo brasileiro vivencia uma notória tendência de delegação de poderes monocráticos aos relatores dos recursos sob o discurso da busca de um processo em tempo razoável e visando 'desobstruir a pauta dos tribunais ao dar preferência a recursos que realmente reclamam a apreciação do colegiado, aqueles em que há matéria controversa'.

Porém, embora a decisão monocrática possa propiciar a solução mais célere da controvérsia $^{97}$, inviabilizou o amplo respeito do princípio da colegialidade no âmbito do STJ. Isto porque, a presente pesquisa demonstrou que a interposição dos recursos de agravo interno e regimental no STJ possui natureza meramente formal. Assim, os recursos não têm o condão de promover o debate material no órgão colegiado acerca da correção da decisão monocrática recorrida. Destarte, é nítido o conflito que se estabelece entre os princípios constitucionais da colegialidade e da duração razoável do processo.

\subsection{A violação do princípio da colegialidade pelo Superior Tribunal de Justiça por ofensa ao postulado da proporcionalidade}

Nessa etapa, já delineados os contornos dos princípios constitucionais da colegialidade e da duração razoável do processo, resta indagar qual deles deve prevalecer, diante do elevado acervo processual do STJ que ameaça o andamento célere dos feitos. Para tanto, utilizar-se-á o método proposto por Ávila ${ }^{98}$, segundo o qual, é necessário questionar a respeito da adequação, da necessidade e da proporcionalidade em sentido estrito, solucionando-se o conflito por aplicação do postulado da proporcionalidade. Para que se aplique o postulado da proporcionalidade deve ser verificada uma relação empírica

\footnotetext{
${ }^{96}$ NUNES, Dierle José Coelho. Colegialidade das decisões dos Tribunais - Sua Visualização como Princípio Constitucional e do Cabimento de Interposição de Agravo Interno de Todas as Decisões Monocráticas do Relator. Revista IOB de Direito Processual Civil, Brasília, v. 9, nº 50, p. 50-61, nov./dez. 2007. p. 52

${ }^{97}$ Pesquisa realizada no âmbito da Justiça Estadual do Rio de Janeiro constatou que a prolação de decisões monocráticas no Tribunal de Justiça do Rio de Janeiro (TJRJ) aumentou a produtividade do tribunal, enfatizando que o julgamento colegiado é três vezes mais lento que o monocrático. (FERRAZ, Leslie Shérida. Acesso à justiça e práticas processuais: decisão monocrática e agravo interno: celeridade ou entrave processual?: A justiça do Rio de Janeiro - 2009. Rio de Janeiro: Fundação Getúlio Vargas, 2009. p. 77). Acesso: 13/10/2019.

98 ÁVILA, Humberto. Teoria dos princípios: da definição à aplicação dos princípios jurídicos. 4. ed., rev. São Paulo: Malheiros, 2005. p. 112-113.
} 
de causalidade, na qual seja possível constatar um meio e um fim. A partir de então são realizados três juízos fundamentais:

$\mathrm{O}$ da adequação (o meio promove o fim?), o da necessidade (dentre os meios disponíveis e igualmente adequados para promover o fim, não há outro meio menos restritivo do(s) direito(s) fundamentais afetados?) e o da proporcionalidade em sentido estrito (as vantagens trazidas pela promoção do fim correspondem às desvantagens provocadas pela adoção do meio? $)^{99}$

Iniciada a análise da adequação, indaga-se: a decisão monocrática no STJ, seguida pelo não provimento e não conhecimento dos recursos de agravo interno e agravo regimental em massa, é um meio adequado para produzir o fim de promoção da celeridade processual? A resposta é afirmativa, posto que o julgamento monocrático geralmente ocorre de forma mais célere que o colegiado, mesmo quando interposto recurso contra a decisão monocrática; inclusive, uma pesquisa realizada no âmbito do TJRJ confirmou tal hipótese ${ }^{100}$.

Em segundo lugar, investiga-se a necessidade da medida. É necessário um exercício de constatação da existência de outros meios alternativos para atingir o mesmo fim. Encontrados os meios, a verificação da necessidade da medida ocorre em duas etapas. $\mathrm{Na}$ primeira, examina-se "a igualdade de adequação dos meios, para verificar se eles promovem igualmente os fins" ${ }^{101}$; na segunda, procede-se o "exame do meio menos restritivo" $" 102$ aos direitos fundamentais.

De fato, existem outros meios que igualmente podem reduzir o acervo processual do STJ, com a finalidade de promover a celeridade processual. Observa-se que a adoção da solução consensual e extrajudicial dos conflitos, com o fito de cessar a crescente interposição de ações judiciais, também teria o condão de reduzir a sobrecarga dos tribunais. Ou, na impossibilidade, estimular a autocomposição no âmbito judicial, vez que as partes raramente interpõem recursos contra decisões homologatórias de acordo, já que,

\footnotetext{
99 ÁVILA, Humberto. Teoria dos princípios: da definição à aplicação dos princípios jurídicos. 4. ed., rev. São Paulo: Malheiros, 2005. p. 112-113.

${ }^{100}$ FERRAZ, Leslie Shérida. Acesso à justiça e práticas processuais: decisão monocrática e agravo interno: celeridade ou entrave processual?: A justiça do Rio de Janeiro - 2009. Rio de Janeiro: Fundação Getúlio Vargas, 2009. p. 77. Acesso: 13/10/2019.

101 ÁVILA, Humberto. Teoria dos princípios: da definição à aplicação dos princípios jurídicos. 4. ed., rev. São Paulo: Malheiros, 2005. p. 122.

102 ÁVILA, Humberto. Teoria dos princípios: da definição à aplicação dos princípios jurídicos. 4. ed., rev. São Paulo: Malheiros, 2005. p. 122
} 
na resolução consensual dos litígios, a solução efetivamente é construída mediante deliberação entre as partes.

No mais, outra medida que contribui para a busca por um processo judicial mais célere é a adoção de medidas administrativas que visam aumentar a produtividade dos órgãos do Poder Judiciário. O planejamento do STJ para o ano de $2020^{103}$, por exemplo, é composto de metas e objetivos que almejam qualificar o quadro de pessoal, melhorar a gestão dos recursos orçamentários e tratar demandas repetitivas e de grandes litigantes, como a fazenda pública.

Com efeito, nota-se que, no período de 2014 a 2019, os três primeiros lugares do ranking de maiores demandantes do STJ foram sucessivamente compostos pelo Instituto Nacional do Seguro Social (INSS), pela Fazenda Nacional e pela União ${ }^{104}$. Diante disso, firmou-se uma parceria entre a Fazenda Nacional e o STJ, a fim de reduzir o número de recursos nas ações de execução fiscal, com baixa probabilidade de satisfação do crédito. A previsão era que até o mês de julho de 2019 cerca de três mil processos deixassem de tramitar perante o $\mathrm{STJ}^{105}$.

Sendo assim, foram constatados outros meios que, assim como a decisão monocrática, podem promover a celeridade processual. Além disso, os novos meios encontrados mostram-se menos gravosos a direitos fundamentais, posto que não ferem o princípio constitucional da colegialidade. Destarte, a decisão monocrática no STJ, seguida pelo não provimento e não conhecimento dos recursos de agravo interno e agravo regimental em massa, é uma medida desnecessária para a promoção da celeridade processual.

Por fim, inicia-se o exame da proporcionalidade em sentido estrito, que segundo Ávila, deve responder ao seguinte questionamento: “O grau de importância da promoção do fim justifica o grau de restrição causado aos direitos fundamentais?"106. Nesta etapa, concluiu-se que a atribuição de competência ao relator e ao presidente do STJ para decidir

\footnotetext{
${ }^{103}$ BRASIL. Superior Tribunal de Justiça. Plano STJ 2020: a base para o futuro que queremos. 3. ed. rev. e atual. Brasília: Superior Tribunal de Justiça, 2018. p. 14-15. Acesso: 17/10/2019.

104 BRASIL. Assessoria de Modernização e Gestão Estratégica Coordenadoria de Gestão da Informação. Boletim estatístico: agosto 2019. Brasília: Superior Tribunal de Justiça, 2019. p. 13-15. Acesso: 14/10/2019.

${ }^{105}$ BRASIL. STJ e Fazenda Nacional firmam parceria para reduzir processos em tramitação. Superior Tribunal de Justiça, Brasília, 03 jun. 2019. Notícias — Institucional. s.p. Acesso: 02/12/2019.

106 ÁVILA, Humberto. Teoria dos princípios: da definição à aplicação dos princípios jurídicos. 4. ed., rev. São Paulo: Malheiros, 2005. p. 124.
} 
monocraticamente matérias cujo juízo natural é o órgão colegiado, sem a observância material do princípio da colegialidade, com a finalidade de alcançar forçadamente a duração razoável do processo, não é proporcional em sentido estrito, pois a medida não justifica o elevado grau de ofensa ao princípio constitucional da colegialidade, conforme será exposto abaixo.

No Estado Democrático de Direito, que impõe um modelo comparticipativo de processo, o princípio da colegialidade no âmbito dos tribunais se apresenta como corolário dos princípios do juízo natural, da ampla defesa e do contraditório como garantia de influência e não surpresa. Ademais, o princípio da razoável duração do processo, embora também amparado constitucionalmente ${ }^{107}$ e por tratados internacionais sobre direitos humanos $^{108}$, não autoriza que seja finalizado o processo da maneira mais rápida possível, desprezando a necessidade de entregar um provimento jurisdicional justo e adequado. Principalmente, porque o ordenamento jurídico brasileiro possui institutos próprios para a tutela de urgência ${ }^{109}$, aplicáveis aos casos em que a demora da cognição exauriente coloque em risco o resultado útil do processo.

Em verdade, a duração razoável do processo se refere à implementação da celeridade de forma que se despenda o tempo necessário para o decurso do devido processo legal, observando todas as garantias constitucionais a ele inerentes ${ }^{110}$. Assim, é certo que a tutela jurisdicional demasiadamente demorada não é eficaz ao fim que se destina, porém é imprescindível a busca de meios que propiciem a duração razoável do

107 Art. 5', inciso LXXVIII, da CRFB: "a todos, no âmbito judicial e administrativo, são assegurados a razoável duração do processo e os meios que garantam a celeridade de sua tramitação." (BRASIL. [Constituição (1988)]. Constituição da República Federativa do Brasil de 1988. Diário Oficial da União, Brasília, 05 out. 2019). Acesso: 25/11/2019.

${ }^{108}$ Convenção Americana sobre Direitos Humanos, art. $8^{\circ}$ : "Toda pessoa tem direito a ser ouvida, com as devidas garantias e dentro de um prazo razoável, por um juiz ou tribunal competente, independente e imparcial, estabelecido anteriormente por lei, na apuração de qualquer acusação penal formulada contra ela, ou para que se determinem seus direitos ou obrigações de natureza civil, trabalhista, fiscal ou de qualquer outra natureza." (BRASIL. Decreto $\mathrm{n}^{\circ}$ 678, de 06 de novembro de 1992. Promulga a Convenção Americana sobre Direitos Humanos (Pacto de São José da Costa Rica), de 22 de novembro de 1969. Diário Oficial da União, Brasília, 09 nov. 1992). Acesso: 19/11/2019.

${ }^{109}$ No âmbito processual civil destaca-se o art. 300 e seguintes do CPC, que dispõem sobre os requisitos de concessão da tutela provisória de urgência.

${ }^{110}$ NUNES, Dierle José Coelho. Colegialidade das decisões dos Tribunais - Sua Visualização como Princípio Constitucional e do Cabimento de Interposição de Agravo Interno de Todas as Decisões Monocráticas do Relator. Revista IOB de Direito Processual Civil, Brasília, v. 9, nº 50, p. 50-61, nov./dez. 2007. p. 60. 
processo, sem que isso importe em violação do princípio da colegialidade no STJ. Neste sentido, Nunes ${ }^{111}$ alerta:

Processo democrático não é aquele instrumento formal que aplica o direito com rapidez máxima, mas, sim, aquela estrutura normativa constitucionalizada que é dimensionada por todos os princípios constitucionais dinâmicos, como o contraditório, a ampla defesa, o devido processo constitucional, a celeridade, o direito ao recurso, a fundamentação racional das decisões, o juízo natural e a inafastabilidade do controle jurisdicional.

Por todo o exposto, é inconstitucional a prática adotada pelo STJ, que impossibilita o reexame material pelo órgão colegiado da decisão monocrática proferida pelo relator ou presidente. Isto porque, constatou-se que do total de recursos interpostos contra as decisões monocráticas apenas $3 \%$ (três por cento) foram julgados providos ou parcialmente providos. Acrescenta-se a isso a verificação de que os recursos não tiveram o condão de alterar substancialmente a decisão monocrática ou possibilitar a reabertura do debate perante o órgão colegiado, ante a concordância em massa dos demais julgadores com o voto do relator.

Ademais, a duração razoável do processo não depende exclusivamente da ação estatal, posto que as partes, ao observarem o dever de lealdade processual, contribuem para um processo justo e célere. Segundo Gomes e Ferreira, esse ideal de processo justo está diretamente atrelado à ética entre as partes, as quais devem evitar "dilações imprestáveis e procrastinações injustificáveis, mais do que isso, é imprescindível que as partes proponham uma célere tramitação procedimental com ações positivas tendentes a simplificar ritos e comandos da lei processual" ${ }^{112}$. Destarte, a busca por um processo judicial democrático que respeite a duração razoável do processo, bem como os outros direitos e garantias constitucionais deve, necessariamente, partir de uma atuação simultânea entre as partes e o poder público $^{113}$.

Neste contexto, a possibilidade de condenar o agravante ao pagamento de multa ao agravado, quando constatado que o agravo interno é manifestamente inadmissível ou

\footnotetext{
111 NUNES, Dierle José Coelho. Processo jurisdicional democrático: Uma análise crítica das reformas processuais. 2 reimpr. Curitiba: Juruá, 2010. p. 250.

112 GOMES, Magno Federici; FERREIRA, Leandro José. A dimensão jurídico-política da sustentabilidade e o direito fundamental à razoável duração do procedimento. Revista do Direito, Santa Cruz do Sul, v. 2, n 52 , p. 93-111, maio/set. 2017. p. 107. Acesso: 28/08/2019.

${ }^{113}$ GOMES, Magno Federici; FERREIRA, Leandro José. A dimensão jurídico-política da sustentabilidade e o direito fundamental à razoável duração do procedimento. Revista do Direito, Santa Cruz do Sul, v. 2, nº 52, p. 93-111, maio/set. 2017. p. 108. Acesso: 28/08/2019.
} 
improcedente, apresenta-se como um mecanismo voltado a coibir a interposição infundada do recurso, com o simples fim de "atrasar" o curso processual. Tal conduta viola a boa-fé objetiva e o dever de cooperação, sendo acertada a previsão contida nos $\S \S 4^{\mathrm{a}}$ e $5^{\mathrm{o}}$ do art. 1021 do CPC, posto que contribui sobremaneira para a razoável duração do processo.

Além disso, a apreciação da controvérsia pelo órgão colegiado tem a função de inibir a contaminação do provimento judicial por vieses cognitivos e também pode contribuir para a duração razoável do processo, posto que a parte tende a não se insurgir contra a decisão formada sob o contraditório como garantia de influência e não surpresa, respeitando o modelo policêntrico de processo também nos tribunais. Nesta perspectiva, Chaves ${ }^{114}$ considera que:

A aplicação conjugada da garantia do juízo natural e do contraditório como influência e não surpresa, por meio do princípio constitucional da colegialidade poderá promover uma diminuição da atividade processual das instâncias recursais, vez que ao perceber que todo o conjunto argumentativo formulado por todos os sujeitos processuais foi levado em consideração no momento da tomada da decisão pluripessoal, a parte vencida poderá desistir de interpor qualquer irresignação recursal ou mesmo reduzir as chances de acatamento de novo recurso a ser interposto pela parte sucumbente.

Por fim, para solucionar o impasse sugere-se que o Superior Tribunal de Justiça adote a sustentação oral no agravo interno e no agravo regimental, mediante disposição em seu regimento interno, conforme autorizado pelo inciso IX do art. 937, do CPC. Isto porque, a sustentação oral tem o condão de aprimorar a finalidade do princípio da colegialidade que é promover o debate entre os integrantes do órgão colegiado e entre eles e as partes. Desse modo, a oralidade contribui para a construção de uma decisão judicial livre do excesso de interferência subjetiva e formada pela participação de todos os julgadores em conjunto com as partes, bem como pelo exercício do contraditório como garantia de influência nas decisões judiciais, o que possibilita atender amplamente o modelo policêntrico de processo. De acordo com Santos ${ }^{115}$ :

A oralidade é importante também para chamar a atenção do colegiado para questões de fato ou quando há a percepção de que o relator exerce influência sobre esse mesmo colegiado, agindo como um equilíbrio de

114 CHAVES, Jéssica Galvão. Princípio constitucional da colegialidade na formação da decisão pluripessoal. 154f. 2017. Dissertação (Mestrado em Direito) - Pontifícia Universidade Católica de Minas Gerais, Belo Horizonte, 2017. p. 153. Acesso: 13/10/2019.

115 SANTOS, Carlos Victor Nascimento dos. A colegialidade nos tribunais: quando uma ideologia vira dogma e o dogma um princípio. Revista estudos institucionais, Rio de Janeiro, v. 3, nº 1, p. 475-524, jul. 2017. p. 489. Acesso: 17/11/2019. 
forças, conforme Mortara, sendo possível inferir que a oralidade manifestada na sustentação oral do advogado perante o colegiado como uma tentativa de convencimento aos membros do colegiado.

Para encerrar, frisa-se que, no Estado Democrático de Direito, o Poder Judiciário desempenha relevante função constitucional de "promover o tratamento dos conflitos, sempre objetivando assegurar e harmonizar dialeticamente a fruição dos direitos fundamentais e imputar o respeito e o cumprimento dos deveres fundamentais" ${ }^{116}$. Diante disso, conclui-se que não pode o próprio Poder Judiciário instituir práticas que visam furtar dos jurisdicionados as garantias e direitos assegurados constitucionalmente, a fim de promover a celeridade processual a qualquer custo, com o escopo de efetivar o princípio da duração razoável do processo, através de meios altamente gravosos a outros princípios constitucionais.

\section{CONSIDERAÇÕES FINAIS}

No período pós-positivista, o neoconstitucionalismo foi responsável por atribuir força normativa aos princípios constitucionais e reconhecer a sua função de assegurar valores inerentes ao Estado Democrático de Direito. À vista disso, verificou-se que, na atualidade, a jurisdição enfrenta o desafio hermenêutico de construir decisões judiciais pautadas pela ponderação de valores e princípios e pela comparticipação dos sujeitos processuais. Dessa forma, uma decisão judicial justa é aquela que observa o devido processo constitucional.

Nesta perspectiva, identificou-se o caráter constitucional do princípio da colegialidade, partindo da constatação de que o órgão colegiado é o juiz natural dos recursos e processos de competência originária dos tribunais pois, no Brasil, é inerente aos tribunais a formação de decisões pluripessoais, ou seja, por deliberação entre os julgadores. Isto está implicitamente previsto na CRFB que enumera os órgãos integrantes do poder judiciário e estabelece o que lhes compete. Especificamente, em relação ao STJ, a CRFB determina tanto a sua composição colegiada quanto a sua competência, nos art. 104 e 105.

Além disso, demonstrou-se o caráter constitucional do princípio da colegialidade em razão dele possibilitar a atenuação da interferência de vieses de cognição, inerentes ao

${ }^{116}$ BODNAR, Zenildo. Os novos desafios da jurisdição para a sustentabilidade na atual sociedade de risco. Veredas do Direito, Belo Horizonte, v.6. nº 12, p. 101-119, jul./dez. 2009. p. 112. Acesso: 28/08/2019. 
ser humano, na formação da decisão judicial, efetivando o princípio da imparcialidade, fundamental ao Estado Democrático de Direito. Isto porque, a decisão colegiada, que possibilita um intenso debate entre o julgador e seus pares, reduz o risco de prevalecer uma decisão judicial eivada de preconcepções oriundas de um dos julgadores a respeito do caso em julgamento, assegurando maior grau de respeito ao princípio da imparcialidade. Dessa forma, percebeu-se que, no modelo democrático de processo, o policentrismo deve ser observado não só na relação entre o Estado-Juiz e as partes, mas também na relação entre os integrantes do órgão colegiado, de maneira que todos influenciem no provimento final.

Em que pese todos os benefícios do julgamento colegiado para a obtenção do devido processo constitucional, no Brasil, os poderes atribuídos ao relator e ao presidente dos tribunais foram majorados, possibilitando decisões monocráticas no julgamento de recursos e ações de competência originária dos tribunais. Isto com o objetivo de aumentar a celeridade da tramitação processual, diante do exacerbado volume do acervo processual dos tribunais.

Contra essas decisões monocráticas proferidas nos tribunais são cabíveis os recursos de agravo interno e de agravo regimental. Os recursos, no geral, proporcionam o exercício do contraditório e da ampla defesa em fase das decisões judiciais. O agravo interno e o agravo regimental cumprem, ainda, a função de efetivar o princípio da colegialidade, porquanto possibilitam que a decisão unipessoal proferida no tribunal seja apreciada pelo órgão colegiado.

Tendo em vista o exposto acima, realizou-se uma pesquisa quantitativa a fim de analisar o respeito ao princípio da colegialidade no STJ. Constatou-se que o número de decisões monocráticas proferidas no STJ supera, aproximadamente, quatro vezes o número de decisões colegiadas. Não obstante, o agravo interno e o agravo regimental não cumpriram a função de proporcionar a análise da decisão monocrática pelo órgão colegiado. Isto porque, apenas 3\% (três por cento) dos recursos foram providos ou parcialmente providos e a maioria destes não alterou substancialmente a decisão monocrática. Além disso, mesmo que a maior parte dos recursos não tenha natureza manifestamente improcedente ou inadmissível, houve concordância em massa com o voto proferido pelo relator. 
Diante disso, exposta a atual situação do acervo processual do STJ, verificou-se que o elevado número de processos em tramitação neste tribunal prejudica o andamento célere dos feitos, ofendendo o princípio da razoável duração do processo. Assim, a decisão monocrática teria a função de proporcionar o julgamento célere dos processos no STJ, posto que a morosidade é um entrave à eficácia da tutela jurisdicional. Tal situação evidencia um conflito entre o princípio da razoável duração do processo e o princípio da colegialidade, que foi solucionado à luz do postulado da proporcionalidade.

Inicialmente, percebeu-se que a decisão monocrática, seguida pelo não conhecimento e não provimento em massa dos recursos de agravo interno e agravo regimental, de fato, é uma medida adequada para o fim de dar maior celeridade ao andamento dos feitos em tramitação no STJ. No entanto, constatou-se que a prática não é necessária, posto que existem outras medidas igualmente eficazes e menos gravosas para atingir o mesmo fim. Cite-se que o afastamento de demandas com alta probabilidade de autocomposição do âmbito do poder judiciário também poderia contribuir para a redução do acervo e para a celeridade processual. Outras medidas foram mencionadas, como a melhor gestão de recursos orçamentários, o trato de demandas repetitivas e de grandes litigantes.

Além disso, a medida adotada pelo STJ também não é proporcional em sentido estrito, pois o fim de atingir a celeridade processual não justifica a elevada restrição ao princípio da colegialidade. Neste espeque, o princípio da razoável duração do processo não pode ser priorizado em detrimento do princípio da colegialidade, que além de ser corolário do princípio do juízo natural, possibilita o exercício de outras garantias constitucionais, como o contraditório e a ampla defesa. $\mathrm{Na}$ atualidade, não é admissível a supressão de direitos essenciais ao Estado Democrático de Direito, em prol da redução do acervo dos tribunais pela promoção de uma celeridade processual que observa apenas critérios formais e quantitativos. Por isso, conclui-se que é inconstitucional a prática adotada pelo STJ, posto que impossibilita o reexame material pelo órgão colegiado da decisão monocrática proferida pelo relator ou presidente. 


\section{REFERÊNCIAS:}

ALEXY, Robert. Teoria dos direitos fundamentais. Tradução de Virgílio Afonso da Silva. 2. ed. São Paulo: Malheiros, 2008.

ÁVILA, Humberto. Teoria dos princípios: da definição à aplicação dos princípios jurídicos. 4. ed., rev. São Paulo: Malheiros, 2005.

BARROSO, Luís Roberto. Fundamentos teóricos e filosóficos do novo direito constitucional brasileiro. Revista da EMERJ, Rio de Janeiro, v. 4, nº 15, p. 11-47, 2001.

Disponível

em: http://www.emerj.tjrj.jus.br/revistaemerj_online/edicoes/revista15/revista15_11.pdf

BODNAR, Zenildo. Os novos desafios da jurisdição para a sustentabilidade na atual sociedade de risco. Revista Veredas do Direito, Belo Horizonte, v. 6, nº 12, p. 101119, jul./dez. 2009. Disponível em: http://www.domhelder.edu.br/revista/index.php/veredas/article/view/19/134.

BRASIL. Assessoria de Modernização e Gestão Estratégica Coordenadoria de Gestão da Informação. Boletim estatístico: agosto 2019. Brasília: Superior Tribunal de Justiça, 2019.

em: http://www.stj.jus.br/webstj/Processo/Boletim/verpagina.asp?vPag=0\&vSeq=338.

BRASIL. [Código de Processo Civil]. Lei n 13.105, de 16 de março de 2015. Código de Processo Civil. Diário Oficial da União, Brasília, 17 mar. 2015. Disponível em: http://www.planalto.gov.br/ccivil_03/_ato2015-2018/2015/lei/113105.htm.

BRASIL. [Constituição (1988)]. Constituição da República Federativa do Brasil de 1988. Diário Oficial da União, Brasília, 05 out. 2019. Disponível em: http://www.planalto.gov.br/ccivil_03/Constituicao/Constituicao.htm.

BRASIL. Decreto nº 678, de 06 de novembro de 1992. Promulga a Convenção Americana sobre Direitos Humanos (Pacto de São José da Costa Rica), de 22 de novembro de 1969. Diário Oficial da União, Brasília, 09 nov. 1992. Disponível em: http://www.planalto.gov.br/ccivil_03/decreto/D0678.htm.

BRASIL. Lei $\mathrm{n}^{\circ} 8.038$, de 28 de maio de 1990. Institui normas procedimentais para os processos que especifica, perante o Superior Tribunal de Justiça e o Supremo 
Tribunal Federal. Diário Oficial da União, Brasília, 29 maio 1990. Disponível em: http://www.planalto.gov.br/ccivil_03/leis/L8038.htm.

BRASIL. Mensagem n ${ }^{\circ}$ 56, de 16 de março de 2015. Diário Oficial da União, Brasília, 17 mar. 2015. Disponível em: http://www.planalto.gov.br/ccivil_03/_Ato20152018/2015/Msg/VEP-56.htm.

BRASIL. Regimento Interno. Brasília: Superior Tribunal de Justiça, 2019. Disponível em: https://ww2.stj.jus.br/publicacaoinstitucional//index.php/Regimento/article/view/31 $15 / 3839$.

BRASIL. Superior Tribunal de Justiça. Pesquisa de jurisprudência do STJ. Brasília: Superior Tribunal de Justiça. Disponível em: https://scon.stj.jus.br/SCON/.

BRASIL. Superior Tribunal de Justiça. Plano STJ 2020: a base para o futuro que queremos. 3. ed. rev. e atual. Brasília: Superior Tribunal de Justiça, 2018. Disponível em: http://www.stj.jus.br/static_files/STJ/Institucional/Gestão\%20estratégica/Plano_ST J_2020_26_OUT2018.pdf.

BRASIL. STJ e Fazenda Nacional firmam parceria para reduzir processos em tramitação. Superior Tribunal de Justiça, Brasília, 03 jun. 2019. Notícias - Institucional. Disponível em: http://www.stj.jus.br/sites/portalp/Paginas/Comunicacao/Noticias/STJ-e-FazendaNacional-firmam-parceria-para-reduzir-processos-em-tramitacao.aspx.

CARVAlHO, Fabiano. Poderes do Relator nos Recursos: art. 557 do CPC - Col. Theotonio Negrão. São Paulo: Saraiva, 2008. Disponível em: https://integrada.minhabiblioteca.com.br/\#/books/9788502145627/.

CHAVES, Jéssica Galvão. Princípio constitucional da colegialidade na formação da decisão pluripessoal. 154f. 2017. Dissertação (Mestrado em Direito) - Pontifícia Universidade Católica de Minas Gerais, Belo Horizonte, 2017. Disponível em: http://www.biblioteca.pucminas.br/teses/Direito_ChavesJG_1.pdf.

COSTA, Eduardo José da Fonseca. Levando a imparcialidade a sério: proposta de um modelo interseccional entre direito processual, economia e psicologia. 187f. 2016. Tese (Doutorado em Direito Processual Civil) - Pontifícia Universidade Católica de São Paulo, São Paulo, 2016. Disponível em: 
https://tede2.pucsp.br/bitstream/handle/6986/1/Eduardo\%20Jose\%20da\%20Fonsec a\%20Costa.pdf.

DIDIER JR., Fredie; CUNHA, Leonardo Carneiro da. Curso de direito processual civil: o processo civil nos tribunais, recursos, ações de competência originária de tribunal e querela nullitatis, incidentes de competência originária de tribunal. 13. ed. Salvador: Juspodivm, 2016. V. 3.

DWORKIN, Ronald. Levando os direitos a sério. Tradução de Nelson Boeira. São Paulo: Martins Forense, 2002.

FERNANDES, Ricardo Vieira de Carvalho; BICALHO, Guilherme Pereira Dolabella. Do positivismo ao pós-positivismo jurídico: $\mathrm{O}$ atual paradigma jusfilosófico constitucional. Revista de Informação Legislativa, Brasília, v. 48, n 189, p. 105 131, jan./mar. 2011. Disponível em: https://www2.senado.leg.br/bdsf/bitstream/handle/id/242864/000910796.pdf.

FERRAZ, Leslie Shérida. Acesso à justiça e práticas processuais: decisão monocrática e agravo interno: celeridade ou entrave processual?: A justiça do Rio de Janeiro 2009. Rio de Janeiro: Fundação Getúlio Vargas, 2009. Disponível em: https://bibliotecadigital.fgv.br/dspace/bitstream/handle/10438/4143/Ferraz\%20$\% 20$ Decis\%c3\%a3o\%20monocr\%c3\%a1tica\%20e\%20agravo\%20interno.pdf?sequ ence $=1 \&$ is Allowed $=\mathrm{y}$.

GOMES, Magno Federici. Do amplo acesso à juridição e da (in) aplicabilidade da retenção dos recursos especial e extraordinário. Revista Eletrônica de Direito processual, Rio de janeiro, v. 8, nº 8, p. 679-708, jul./dez. 2011. Disponível em: https://www.epublicacoes.uerj.br/index.php/redp/article/view/20840/15116.

GOMES, Magno Federici; FERREIRA, Leandro José. A dimensão jurídico política da sustentabilidade e o direito fundamental à razoável duração do procedimento. Revista do Direito, Santa Cruz do Sul, v. 2, n 52, p. 93-111, maio/set. 2017. Disponível em: http://dx.doi.org/10.17058/rdunisc.v2i52.8864.

GOMES, Magno Federici; MARTINS, Márcia de Azevedo. A inconstitucionalidade do artigo 475 do Código de Processo Civil: violação aos princípios da isonomia, proporcionalidade e efetividade do procedimento. Revista Eletrônica de Direito 
Processual, Rio de Janeiro, v. 6, nº 6, p. 428-474, jul./dez. 2010. Disponível em: https://www.e-publicacoes.uerj.br/index.php/redp/article/view/21580/15583.

KELSEN, Hans. Teoria pura do direito. Tradução de João Batista Machado. 6. ed. São Paulo: Martins Fontes, 1998.

MEDINA, José Miguel Garcia. Curso de Direito Processual Civil Moderno. 3. ed. São Paulo: Revista dos Tribunais, 2017.

NUNES, Dierle José. A função contrafática do Direito e Novo CPC. Revista do Advogado, São Paulo, v. 35, $\mathrm{n}^{\mathrm{o}}$ 126, p. 51-55, maio 2015. Disponível em: https://www.academia.edu/12752172/A_função_contrafática_do_Direito_e_o_Nov o_CPC.

NUNES, Dierle José Coelho. Colegialidade das decisões dos Tribunais: sua visualização como princípio constitucional e do cabimento de interposição de agravo interno de todas as decisões monocráticas do relator. Revista IOB de Direito Processual Civil, Brasília, v. 9, $\mathrm{n}^{\mathrm{o}}$ 50, p. 50-61, nov./dez. 2007. Disponível em: https://www.academia.edu/4563683/Colegialidade_e_agravo_interno__Dierle_Nunes.

NUNES, Dierle José Coelho. Direito Constitucional ao Recurso: da teoria geral dos recursos, das reformas processuais e da comparticipação nas decisões. Rio de Janeiro: Lumen Juris, 2006. Disponível em: https://www.academia.edu/38939634/DIREITO_CONSTITUCIONAL_AO_RECU RSO_Da_teoria_geral_dos_recursos_das_reformas_processuais_e_da_comparticip ação_nas_decisões.

NUNES, Dierle; DELFINO, Lúcio. Novo CPC: enunciados de súmula e pseudo colegialidade. Justificando, São Paulo, 28 ago. 2014. Disponível em: http://www.justificando.com/2014/08/28/novo-cpc-enunciados-de-sumula-epseudo-colegialidade/.

NUNES, Dierle; SILVA, Natanael Lud Santos; PEDRON, Flávio Quinaud. Desconfiando da imparcialidade dos sujeitos processuais: um estudo sobre os vieses cognitivos, a mitigação de seus efeitos e o debiasing. Salvador: Juspodivm, 2018.

NUNES, Dierle José Coelho. Processo jurisdicional democrático: uma análise crítica das reformas processuais. 2 reimpr. Curitiba: Juruá, 2010. 
SANTOS, Carlos Victor Nascimento dos. A colegialidade nos tribunais: quando uma ideologia vira dogma e o dogma um princípio. Revista estudos institucionais, Rio de Janeiro, v. 3, $\mathrm{n}^{\mathrm{o}}$ 1, p. 475-524, jul. 2017. Disponível em: https://www.estudosinstitucionais.com/REI/article/view/100/139.

SCARPINELlA BUENO, Cassio. Manual de direito processual civil. 4. ed. São Paulo: Saraiva, 2018.

SILVA, Natanael Lud. Os vieses de cognição e o processo jurisdicional democrático: um estudo sobre a mitigação de seus efeitos e o debiasing. 128f. 2018. Dissertação (Mestrado em Direito) - Pontifícia Universidade Católica de Minas Gerais, Belo Horizonte, 2018. Disponível em: http://www.biblioteca.pucminas.br/teses/Direito_SilvaNLS_1.pdf.

THEODORO JUNIOR, Humberto. Curso de Direito Processual Civil. 50 ed. Rio de Janeiro: Forense, 2017. V. 3.

THEODORO JUNIOR, Humberto; NUNES, Dierle; BAHIA, Alexandre; PEDRON, Flávio. Novo CPC: Fundamentos e sistematização. 3. ed. Rio de Janeiro: Forense, 2016.

TORRES, Ricardo Lobo. O mínimo existencial e os direitos fundamentais. Revista de Direito Administrativo, Rio de Janeiro, v. 177, p. 29-49, jul./set. 1989. Disponível em: http://bibliotecadigital.fgv.br/ojs/index.php/rda/article/view/46113/44271.

VEREA, Larissa. O aumento dos poderes do relator e o julgamento monocrático dos recursos cíveis. 187f. 2014. Dissertação (Mestrado em Direito) - Faculdade de Direito da Universidade de São Paulo, São Paulo, 2014. Disponível em: https://www.teses.usp.br/teses/disponiveis/2/2137/tde-08122014163918/publico/LARISSA_VEREA_Dissertacao.pdf.

\section{LISTA DE GRÁFICOS:}

\section{Gráfico 1 - Decisões colegiadas e monocráticas proferidas pelo STJ, de janeiro a agosto de 2019, excluídas as liminares e as decisões interlocutórias}


Rio de Janeiro. Ano 16. Volume 23. Número 1. Janeiro a Abril de 2022

Periódico Quadrimestral da Pós-Graduação Stricto Sensu em Direito Processual da UERJ

Patrono: José Carlos Barbosa Moreira (in mem.). ISSN 1982-7636. pp. 872-911 www.redp.uerj.br

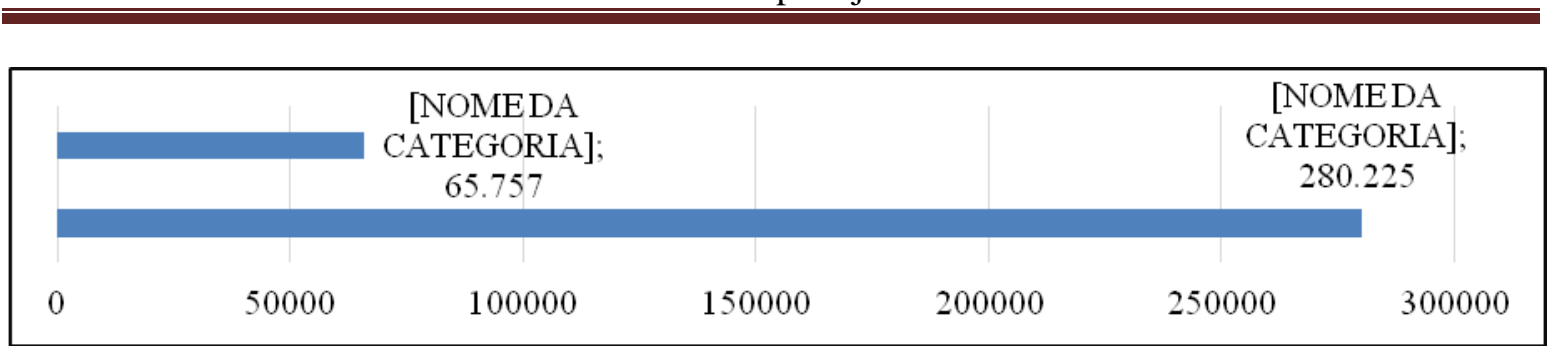

Fonte: Elaborado pelos autores com dados extraídos de Boletim Estatístico: agosto 2019 (2019, p. 29)

Gráfico 2 - resultado do julgamento dos recursos de agravo interno e agravo regimental no STJ de janeiro a agosto de 2019

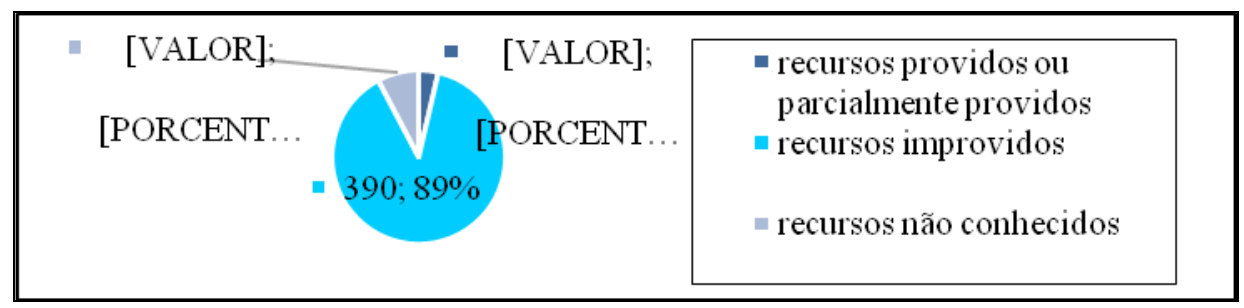

Fonte: Resultado da Pesquisa (2019).

Gráfico 3 - Índice de concordância com o voto proferido pelo relator nos agravos internos e regimentais interposto no STJ de janeiro a agosto de 2019

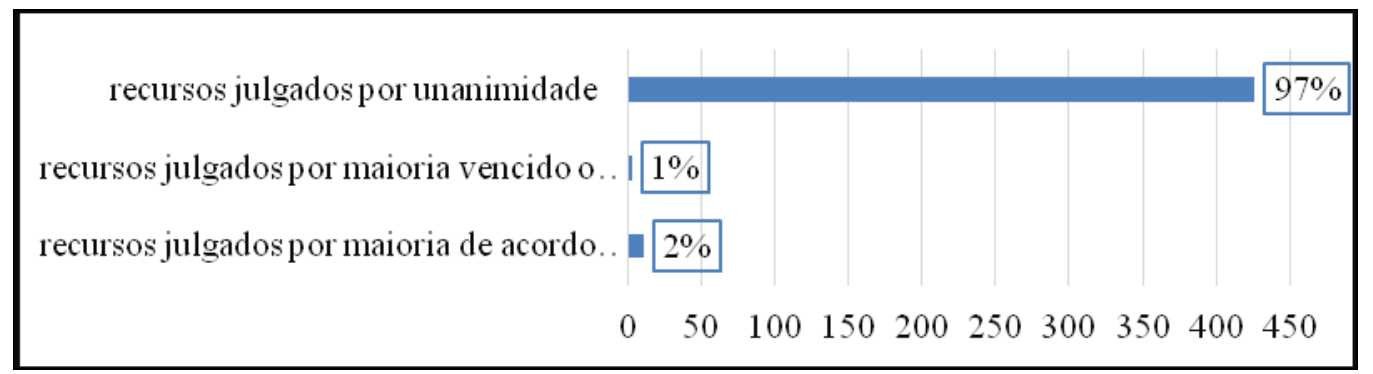

Fonte: Resultado da Pesquisa (2019).

Gráfico 4 - Índice de não provimento ou não conhecimento por unanimidade dos recursos de agravo interno ou regimental interpostos no STJ de janeiro a agosto de 2019

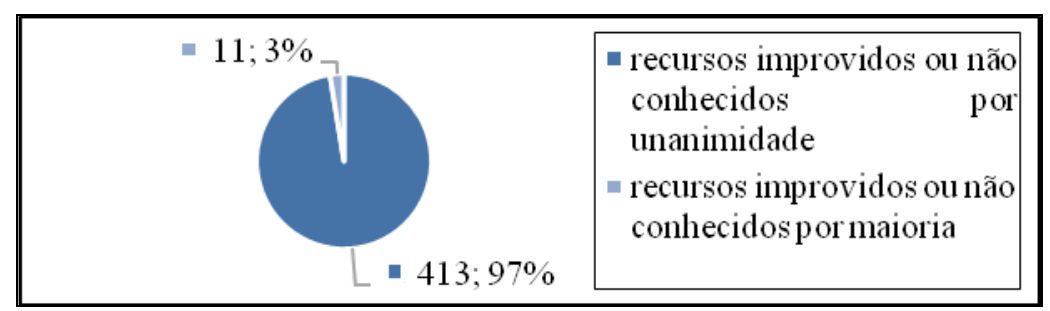

Fonte: Resultado da Pesquisa (2019). 